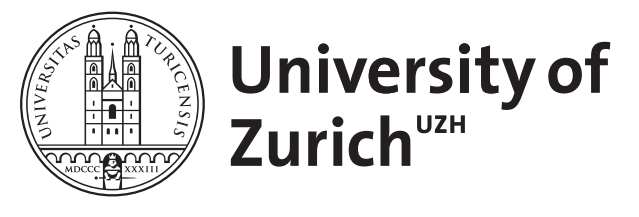

\title{
Glacier mapping: a review with special reference to the Indian Himalayas
}

Bhambri, Rakesh ; Bolch, Tobias

\begin{abstract}
This paper deals with the development of glacier mapping and glacier fl actuation's since the mid-nineteenth century, with special reference to the Indian Himalayas, and the contributions of the Survey of India and the Geological Survey of India. In addition, it presents a review of the limitations and challenges relating to: the mapping of clean-ice and debris-covered glaciers; the comparison of different data sets; and the measurement of glacier volume changes based on multitemporal digital elevation models. Possible solutions are discussed, and the emerging areas of glacier mapping research and applications for the Indian Himalayas are highlighted.
\end{abstract}

DOI: https://doi.org/10.1177/0309133309348112

Posted at the Zurich Open Repository and Archive, University of Zurich ZORA URL: https://doi.org/10.5167/uzh-137192

Journal Article

Published Version

Originally published at:

Bhambri, Rakesh; Bolch, Tobias (2009). Glacier mapping: a review with special reference to the Indian Himalayas. Progress in Physical Geography, 33(5):672-704.

DOI: https://doi.org/10.1177/0309133309348112 
Progress in Physical Geography 33(5) (2009) pp. 672-704

\title{
.
}

\section{Glacier mapping: a review with special reference to the Indian Himalayas}

\section{Rakesh Bhambri ${ }^{1 *}$ and Tobias Bolch ${ }^{2}$}

\author{
'Guru Nanak Khalsa College, Karnal - 132001, Haryana, India \\ ${ }^{2}$ Institut für Kartographie, Technische Universität Dresden, 01069 Dresden, \\ Germany
}

\begin{abstract}
This paper deals with the development of glacier mapping and glacier fluctuations since the mid-nineteenth century, with special reference to the Indian Himalayas, and the contributions of the Survey of India and the Geological Survey of India. In addition, it presents a review of the limitations and challenges relating to: the mapping of clean-ice and debris-covered glaciers; the comparison of different data sets; and the measurement of glacier volume changes based on multitemporal digital elevation models. Possible solutions are discussed, and the emerging areas of glacier mapping research and applications for the Indian Himalayas are highlighted.
\end{abstract}

Key words: ASTER, digital elevation model, glacier fluctuation, glacier mapping, Indian Himalayas, remote sensing.

\section{Introduction}

The principal goal of glacier mapping is to represent the spatial morphology of glacier terrain features on maps. Glacier maps are well established as valuable records of glaciogeomorphic features in particular time periods (Ashwell, 1982). Moreover, using recent geo-informatics techniques, it is possible to prepare 2D/3D digital maps for visualization of glacial terrain (Buckley et al., 2004; Bolch, 2008). Glaciologists can also use these techniques to obtain information about glacier variability (Hall et al., 2003), estimate mass balance (Østrem and Haakensen, 1999;
Andreassen, 1999), infer the morphometric status of glaciated regions (Sangwar et al., 2004), calculate changes in ice volume (Surazakov and Aizen, 2006; Bauder et al., 2007; Bolch et al., 2008), and estimate the position of the equilibrium line (Leonard and Fountain, 2003). However, all such uses are fundamentally governed by the accuracy and availability of the original map resource.

The Himalayas comprise one of the largest collections of glaciers outside the polar regions, with a glacier coverage of $\sim 33,000$ $\mathrm{km}^{2}$ (Dyurgerov and Meier, 1997) and a

*Author for correspondence. Present address: Soil and Crop management division, Central Soil Salinity Research Institute, Kachawa Road, Karnal - 132001, India.

Email: rakeshbhambri@gmail.com

(C) The Author(s), 2009. Reprints and permissions:

DOI: $10.1177 / 0309133309348112$

http://www.sagepub.co.uk/journalsPermissions.nav 
total number of 5243 glaciers (Kaul, 1999; Hasnain, 1999). The Himalayas form a natural barrier between the southern Indian Peninsula and mainland Asia, extending $2500 \mathrm{~km}$ from Pamir Knot in the west to Arunachal Pradesh in the east with the three parallel ranges, the Himadri, Himachal and Shivaliks. Himalayan glaciers in the Indian subcontinent are broadly divided into the three river basins, namely the Indus, Ganga and Brahmaputra (Figure 1). The Indus basin has the largest number of glaciers $(2500)$, whereas the Ganga and Brahmaputra basins contain about 1000 and 660 glaciers, respectively (Kaul, 1999; Hasnain, 1999). Himalayan glaciers are an important source of fresh water for northern Indian rivers and water reservoirs (Kumar et al., 2005). The inventory of Himalayan glaciers indicates that many Himalayan glaciers are receding at an alarming rate (Kulkarni et al., 2005; 2007). Due to the rapid recession of glaciers, a number of catastrophic effects such as glacial lake outburst floods (WWF, 2005; Mool et al., 2007), water scarcity in the upper Himalayan villages and adverse effects on the flow of Himalayan rivers have been reported (Kulkarni et al., 2002; 2007). For water resources planning and management in northern India, it is essential, therefore, to study and monitor the Himalayan glaciers precisely. Advanced remote sensing and GIS techniques offer abundant potential for mapping and monitoring the glaciers in

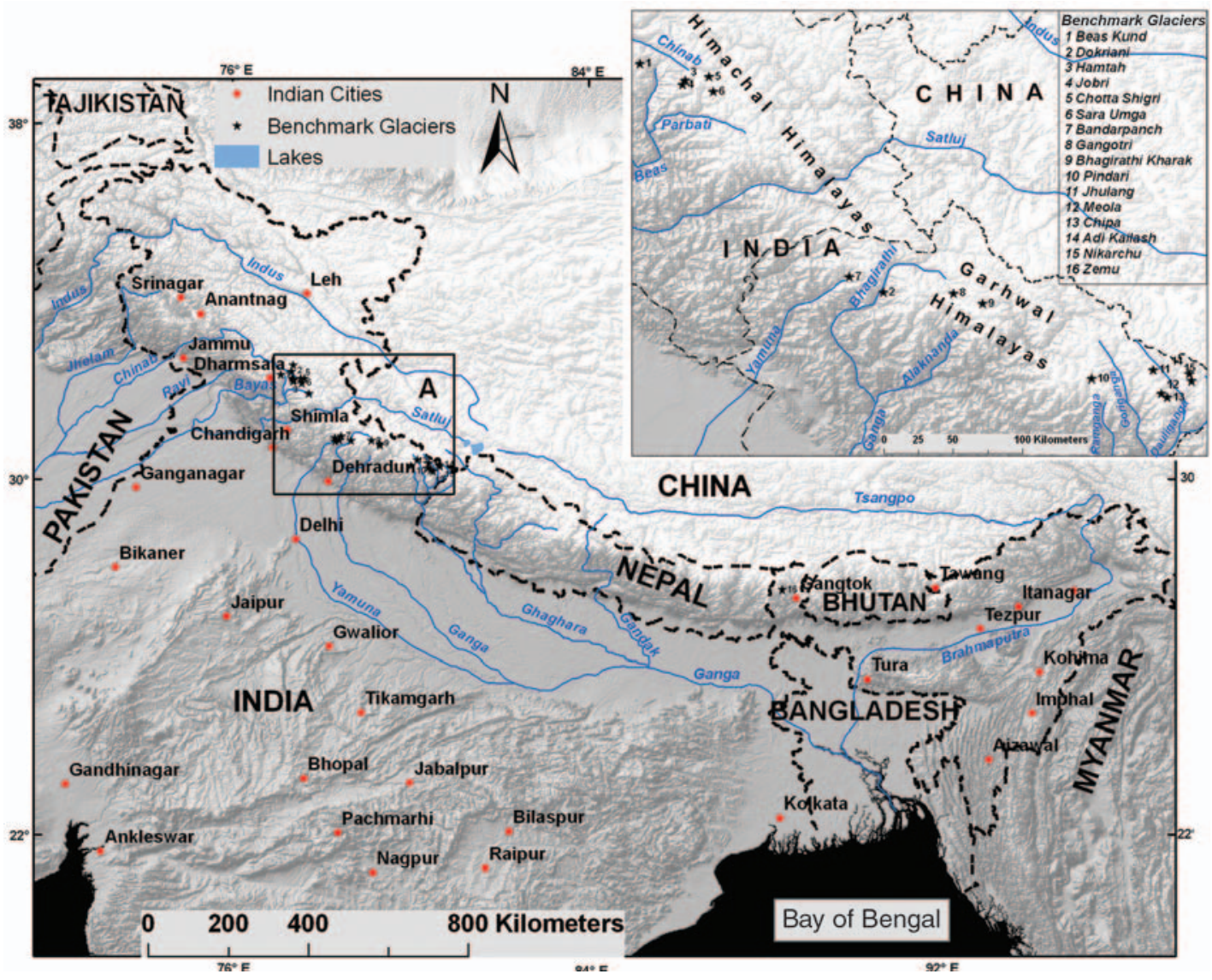

Figure 1 Overview of the Himalayas with the benchmark glaciers in the Indian Himalayas (political boundaries are only tentative) 
extensive high and remote mountain areas, whereas conducting a survey based on conventional methods demands a great deal of time and capital and involves enormous risks.

This paper presents a review of glacier mapping in the Indian Himalayas since the mid-nineteenth century. It also highlights the advantages and problems of remotesensing-based glacier mapping, and sheds light on the emerging areas of national as well as international glacier research and applications, with special reference to the Indian Himalayas. In addition, overviews of the current knowledge on the fluctuations of the Indian Himalayas are also presented.

\section{Topographic glacier mapping since the mid-nineteenth century}

During the early seventeenth century, glacier boundaries and surrounding features were represented as rough sketches. However, the first claim on the making of an accurate large-scale map for glaciological purposes (Venediger Group, Alps) was made by Eduard Richter, the first chairman of the German and Austrian Alpine Club (Brunner, 1987). The history and development of glacier mapping in other countries is well documented by Williams and Ferrigno (1988-2008), yet to this day there is still no such documentation on the Indian Himalayan glaciers. However, more recently, Raina and Srivastava (2008) presented a glacier inventory and historical documentation of the glaciological studies in India, with details for a few selected glaciers. The Survey of India (SOI) is the primary agency of India involved in surveying the Himalayan mountain region since its establishment in 1767. The records of many surveys, especially Colonel Godwin-Austen's plane-table surveys of the Mustakh range (Godwin-Austen, 1864), Conway's journey to the Hisper Glacier in 1892 (Conway, 1893), various expeditions of $\mathrm{Mr}$ and Mrs Visser, and the Shaksgam expedition by Mason and Shipton (Mason, 1927a; Shipton et al., 1938) have made notable contributions to glacier mapping of the Himalayas. All of these surveys and expeditions contributed significant information for tracking the following:

(1) mapping of unexplored valleys, peaks, passes and glacier terrain of the Himalayas;

(2) correcting maps of the earlier Himalayan terrain through improved scientific instruments and advanced techniques;

(3) recognizing a variety of changes within the glacier on the basis of previous glacier snout maps.

In the early nineteenth century, the mapping of Himalayan terrain was carried out using plane-table surveying and heavy theodolites. Purdon (1861) and Godwin-Austen (1864) began the survey and mapping of Himalayan glaciers. The Geological Survey of India (GSI) initiated the monitoring of secular movements of the principal Himalayan glaciers as part of the programme of the Commission International des Glaciers during 1906-1908. Initially, a total of 12 glaciers were studied by the Geological Survey of India (GSI) (Holland, 1907). Plane-table glacier sketches were made for all the glaciers, showing the snout and other geomorphic features. In some cases, cairns were also constructed for further reference.

Workman (1903) found, during an expedition to Baltistan, that glaciers had not always been delineated correctly during the great trigonmetrical survey by Godwin-Austen (1861). Similar conclusions were reached by Longstaff $(1908 ; 1911)$ regarding the Garhwal Himalayas and Eastern Karakoram. Longstaff (1910a) also surveyed the Siachen Glacier in June 1909, and discovered that Siachen was the largest glacier (44 miles) in the Himalayan range. Visser (1926) reported that the delineation of Malangutti Glacier was incorrect on the 1915 Survey Map. Moreover, Mason (1928) established that Indira Col was shown on Workman's' map from his Shaksgam Valley expedition approximately one mile too far northward, 


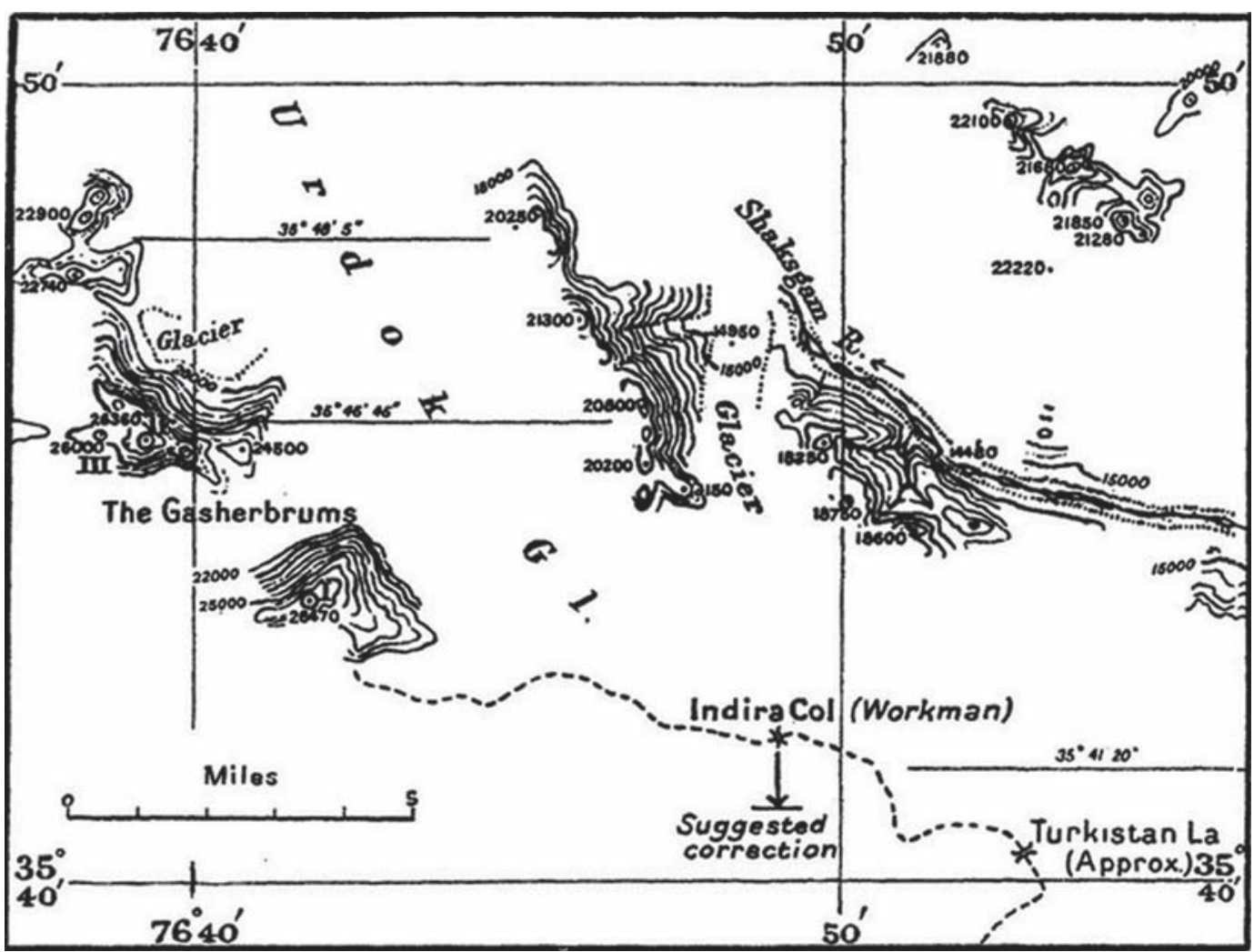

Figure 2 Part of the map illustrating Major Mason's Stereographic Survey of the Shaksgam (October 1927)

Source: Mason (1928). Map published with the permission of the Royal Geographic Society (with IBG).

and he subsequently corrected this (Figure 2). P. Bauer surveyed the Zemu Glacier by terrestrial photogrammetry and prepared a large-scale glacier map (Finsterwalder, 1935). Finsterwalder and Pillewizer (1937) used a stereo-photogrammetry method for the investigation of ice-flowing movement of the Rakhiot Glacier.

Shortcomings in the representation of glacier and geomorphic features on the Survey of India maps were first pointed out by Mason (1929) in his review article. Mason concluded that there is a need to first train surveyors in recognizing the morphology of glaciers and typical glacier features and their movements, before one can expect the glaciers to be surveyed and drawn correctly.
In the review article, Mason proposed colour schemes and guidelines for the representation of glacio-geomorphic features on SOI maps (Table 1) to be replaced by voids in black and white and colour-hachured maps (Figure 3). Historically, glacio-geomorphic features such as ice caps could not be distinguished from rocky summits. Also, sometimes the words 'Glacier' or 'Snow-bed' were written across the blank space on SOI maps. Other details of the cartographic representation are described in Table 2.

Auden (1937) was the first geologist to systematically map the snout and geomorphic features of the Gangotri Glacier using a planetable survey at a scale of 1:4800. J.C. Ross cross-checked the plane-table map in the field. 
Table 1 Colour schemes for glacier-geomorphic features on Survey of India maps (from Mason, 1929)

\begin{tabular}{|c|c|c|c|}
\hline Features & Plane table & Map & Remarks \\
\hline $\begin{array}{l}\text { Limits of all areas of permanent } \\
\text { glaciations, whether glacier } \\
\text { or neve, and all ice features }\end{array}$ & Yellow-green & Blue & $\begin{array}{l}\text { No tint. The limits of the glacier will be } \\
\text { shown by a fine line of dots. }\end{array}$ \\
\hline $\begin{array}{l}\text { Water features whether on } \\
\text { or off ice }\end{array}$ & Violet-blue & Blue & \\
\hline $\begin{array}{l}\text { Live or barren dead moraines, lateral, } \\
\text { medial, or terminal; scree, rockfalls } \\
\text { and fans }\end{array}$ & Black & Black & $\begin{array}{l}\text { Care should be taken to avoid the } \\
\text { appearance of sand. The rocks comprising } \\
\text { moraine are all sizes; the dots should be, too. }\end{array}$ \\
\hline $\begin{array}{l}\text { Dead moraines if under vegetation } \\
\text { (grass, scrub or trees) }\end{array}$ & Burnt Sienna & Brown & \\
\hline $\begin{array}{l}\text { Contours across glaciers and neve, } \\
\text { including those across live moraine }\end{array}$ & Yellow-green & Blue & \\
\hline $\begin{array}{l}\text { Contour values pertaining to the } \\
\text { above: } \\
\text { (a) across ice and snow } \\
\text { (b) across moraine }\end{array}$ & $\begin{array}{l}\text { Yellow-green } \\
\text { Black }\end{array}$ & $\begin{array}{l}\text { Blue } \\
\text { Black }\end{array}$ & $\begin{array}{l}\text { The contour values may be either } \\
\text { alongside or breaking the contour line, } \\
\text { whichever is most suitable. }\end{array}$ \\
\hline $\begin{array}{l}\text { Contours across hill slopes below } \\
\text { the snowline, across dead } \\
\text { moraines, scree, fans, etc }\end{array}$ & Burnt Sienna & Brown & $\begin{array}{l}\text { Brown contours should never be shown } \\
\text { above the snow-line. Bare ground above } \\
\text { this line must be cliff, and should be shown } \\
\text { by the cliff symbol }\end{array}$ \\
\hline Cliffs above or below the snowline & Burnt Sienna & Brown & \\
\hline Paths, tracks, routes, huts & Red & Red & \\
\hline Passes and names & Black & Black & \\
\hline
\end{tabular}

This map was reproduced at 1:9600 scale by Auden (1937) and formed the basis of more than a dozen studies on the recession of the Gangotri Glacier conducted by the GSI. Several scientists from the GSI resurveyed the Gangotri Glacier and marked the position of the snout on Auden's plane-table map as well as cairns on the ground (eg, Jangpangi, 1958; Tiwari, 1972). A large number of Indian and British surveyors thus used contemporary techniques and instruments for surveying unexplored Himalayan ranges and paved the way for future generations of explorers in mapping the Himalayan peaks and glaciated terrain in extreme climatic and high-altitude conditions.

In the 1960s, the Survey of India published topographical maps of Himalayan glacier terrain on the basis of aerial photographs with limited fieldwork at a scale of 1:50,000. To date, five topographical maps, nos. 53E/5, 9 , 10,13 and 14 , are available in open series maps (OCM) which cover a small segment of Indian Himalayan glaciers. Other topographic maps which cover the remaining, larger segment of Indian glaciers are defence series maps (DSM) and are restricted (Survey of India, 2005). Since the beginning of the twentieth century, GSI have mapped several glacier snouts and surrounding glacio-geomorphic features such as Gangotri, Pindari, Milam, Shankulpa, Gor Garang, Triloknath, Poting and many others for monitoring glacier recession and advance using plane-table mapping. The Survey of India parties, along with GSI, visited several Himalayan glaciers such as Gara Glacier in 1973, Neh-Nar Glacier in 1978 and Dunagiri in 1987 , and then mapped the glacier snout area 


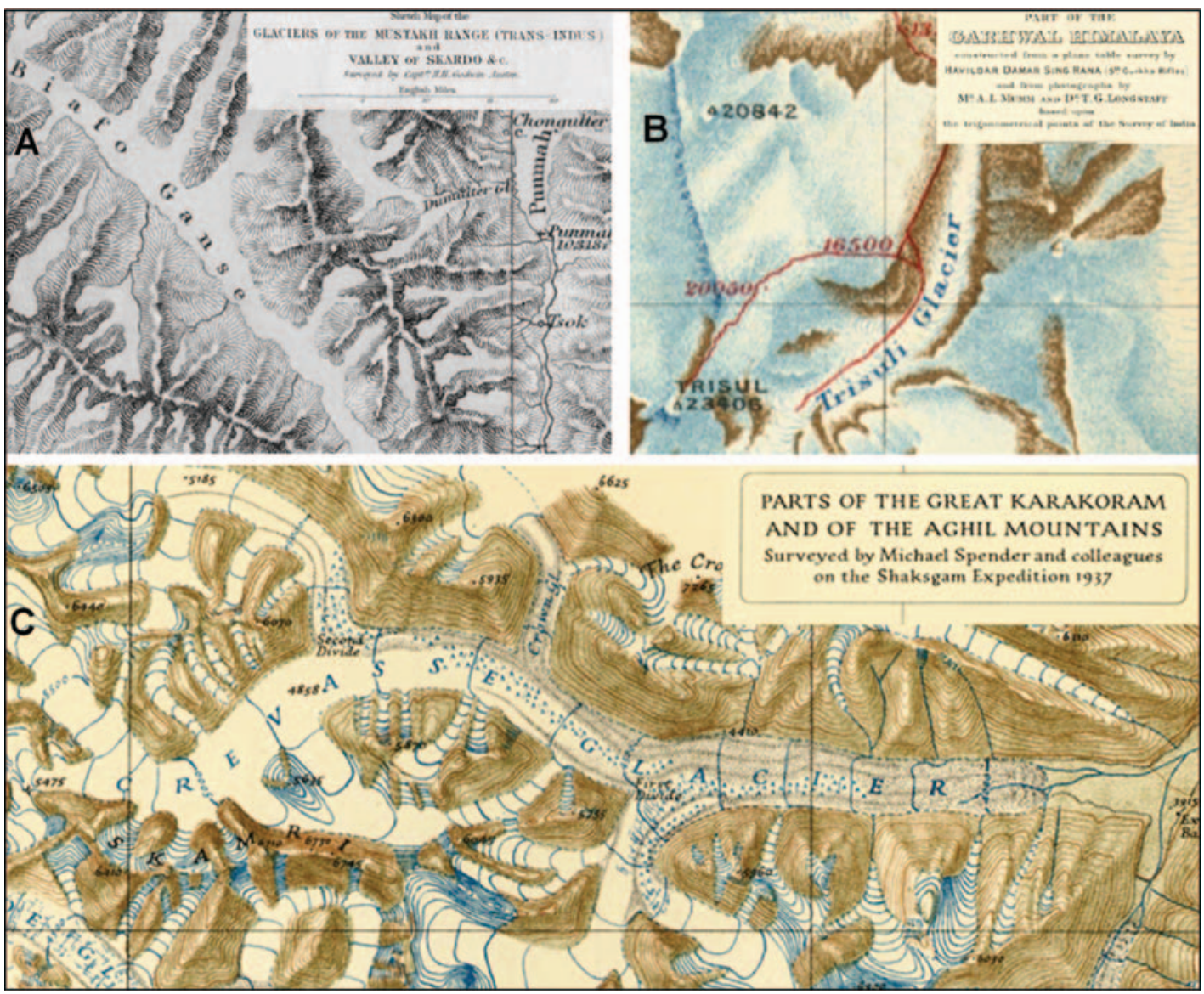

Figure 3 Rearrangement of the topographic glacier map of the Himalayas for visualization. (A) Black-and-white plane-table survey map without contours by Godwin-Austen (1864). (B) Coloured plane-table survey map without contours by Longstaff (1908). (C) Coloured stereo-photography survey map with contours by Shipton et al. (1938). Maps published with the permission of the Royal Geographic Society (with IBG)

at 1:5000 scale (Srivastava, 2001). Agarwal (1989) mapped the Neh-Nar Glacier with a contour interval of $10 \mathrm{~m}$ using the terrestrial photogrammetric technique. A literature review suggests that only three large-scale topographic glacier maps have been prepared by the Survey of India since India obtained its independence in 1947. One of the maps was prepared by SOI for Meru bamak at 1:5000, Garhwal Himalayas, in 1977 (Chitranshiet al., 2004). In 1984 and 1995, SOI prepared maps at a scale of 1:10,000 for Dokriani and
Chotta Shigri Glaciers, respectively (Roy, 2001; Dobhal et al., 2004). These maps were prepared by the SOI during Interdepartmental expeditions. Chaujar (1989) published the first geomorphological map of Chotta Shigri Glacier at a scale of 1:10,000. In contrast, more than a dozen glacier maps had been produced at a scale of 1:10,000 by the end of the nineteenth century, with the development of cartography as an independent discipline (Brunner, 1987). It is noteworthy that in Norway alone as many as 24 
Table 2 Details of glacier mapping during selected expeditions in the Himalayas

\begin{tabular}{|c|c|c|c|c|}
\hline Authors & Location & Surveyors & $\begin{array}{l}\text { Instrument used in } \\
\text { expedition }\end{array}$ & Brief description \\
\hline $\begin{array}{l}\text { Godwin-Austen } \\
(1864)\end{array}$ & $\begin{array}{l}\text { Mustakh } \\
\text { Range }\end{array}$ & $\begin{array}{l}\text { Godwin-Austen } \\
\text { and survey party } \\
\text { from Survey of } \\
\text { India }\end{array}$ & Plane table & $\begin{array}{l}\text { This study is the first survey } \\
\text { of Mustakh range and mapped } \\
\text { Chogo Loombah, Masherbrum, } \\
\text { Bande Loombah, Biafo, Punmah, } \\
\text { Sobfindi and Mustakh Glaciers on } \\
\text { trigonometrical survey map }\end{array}$ \\
\hline $\begin{array}{l}\text { Fanny Bullock } \\
\text { Workman (1906) }\end{array}$ & Baltistan & $\begin{array}{l}\text { Mr Hewett } \\
\text { of London, as } \\
\text { topographer, } \\
\text { Dr William } \\
\text { Hunter Workman } \\
\text { and Mrs Fanny } \\
\text { Bullock Workman }\end{array}$ & Theodolite & $\begin{array}{l}\text { This study mapped Hoh Lumba } \\
\text { and Sosbon Glaciers at 1:250,000 } \\
\text { scale without contours }\end{array}$ \\
\hline Longstaff (1908) & $\begin{array}{l}\text { Garhwal } \\
\text { Himalayas }\end{array}$ & $\begin{array}{l}\text { Subhadar Karbir } \\
\text { Burathoki, } \\
\text { Havildar Damar } \\
\text { Singh Rana, and } \\
\text { seven riflemen } \\
\text { from 5th Gurkha } \\
\text { Rifles }\end{array}$ & $\begin{array}{l}\text { Plane table, } \\
\text { Hypsometers and } \\
\text { Watkins mountain } \\
\text { aneroid for } \\
\text { metrological data } \\
\text { collection }\end{array}$ & $\begin{array}{l}\text { This study mapped more than a } \\
\text { dozen glaciers, such as Bagini, } \\
\text { Trisuli, Betatoli, kamet, Dunagiri, } \\
\text { Juma, Ravikana, Banke, Bhyunder, } \\
\text { Khaiam, Bidum, Abijurun, } \\
\text { Sukeram, and Maiktoli, using } \\
\text { plane-table and trigonometrical } \\
\text { points from Survey of India at } \\
\text { 1:250,000 scale }\end{array}$ \\
\hline Longstaff (1910b) & $\begin{array}{l}\text { Eastern } \\
\text { Karakoram }\end{array}$ & Longstaff & $\begin{array}{l}\text { Plane table, } \\
\text { theodolite, } \\
\text { clinometers }\end{array}$ & $\begin{array}{l}\text { Topographic map was prepared } \\
\text { showing Rgyong, Bawoni, Beltus, } \\
\text { Chulung, Korisa, and many other } \\
\text { glaciers at 1:500,000 scale without } \\
\text { contours }\end{array}$ \\
\hline $\begin{array}{l}\text { Filippo de Filippi } \\
\text { (1911) }\end{array}$ & $\begin{array}{l}\text { Karakoram } \\
\text { Himalayas }\end{array}$ & $\begin{array}{l}\text { Lieutenant } \\
\text { Negrotto }\end{array}$ & $\begin{array}{l}\text { Paganini's } \\
\text { photogrammetry } \\
\text { supplemented by } \\
\text { theodolite } \\
\text { Mensuration, } \\
\text { mercurial Fortin } \\
\text { barometers, } \\
\text { aneroids, and } \\
\text { hypsometers }\end{array}$ & $\begin{array}{l}\text { In this study, Godwin-Austen } \\
\text { Glacier and Baltoro Glacier } \\
\text { mapped using intersection } \\
\text { photogrammetric method at } \\
\text { 1:125,000 scale }\end{array}$ \\
\hline $\begin{array}{l}\text { Mason } \\
(1914)\end{array}$ & $\begin{array}{l}\text { Pamir } \\
\text { mountain } \\
\text { region }\end{array}$ & Mason & $\begin{array}{l}\text { Thompson } \\
\text { phototheodolite }\end{array}$ & $\begin{array}{l}\text { Mason introduced stereo- } \\
\text { photography method devised by } \\
\text { Captain Vivian Thompson, R.E., } \\
\text { in Pamir mountain region }\end{array}$ \\
\hline $\begin{array}{l}\text { Mason } \\
(1927 a)\end{array}$ & Shaksgam & $\begin{array}{l}\text { Khan Sahib } \\
\text { Afraz Gul Khan }\end{array}$ & $\begin{array}{l}\text { Wild } \\
\text { phototheodolite }\end{array}$ & $\begin{array}{l}\text { Mason prepared a topographic } \\
\text { map of Kyagar Glacier at 1:50,000 } \\
\text { scale using stereoscopic survey } \\
\text { with contour interval of } 250 \mathrm{ft}\end{array}$ \\
\hline
\end{tabular}


Table 2 Continued

\begin{tabular}{|c|c|c|c|c|}
\hline Authors & Location & Surveyors & $\begin{array}{l}\text { Instrument used in } \\
\text { expedition }\end{array}$ & Brief description \\
\hline $\begin{array}{l}\text { Mason } \\
\text { (1927b) }\end{array}$ & $\begin{array}{l}\text { Shaksgam } \\
\text { Valley } \\
\text { and Aghil } \\
\text { Range }\end{array}$ & $\begin{array}{l}\text { Khan Sahib } \\
\text { Afraz Gul Khan }\end{array}$ & $\begin{array}{l}\text { Wild } \\
\text { phototheodolite }\end{array}$ & $\begin{array}{l}\text { Mason prepared a topographic } \\
\text { map of Shaksgam Valley and Aghil } \\
\text { Range at 1:250,000 scale with } \\
\text { contour interval of } 500 \mathrm{ft} \text {. In this } \\
\text { expedition, Mason successfully } \\
\text { demonstrated contouring of K2 } \\
\text { Glacier terrain at a distance of } \\
42 \text { miles by terrestrial stereo- } \\
\text { photogrammetry }\end{array}$ \\
\hline Visser (1926) & $\begin{array}{l}\text { West of } \\
\text { Hunza } \\
\text { river, } \\
\text { Karakoram }\end{array}$ & $\begin{array}{l}\text { Khan Afraz } \\
\text { Gul Khan from } \\
\text { Survey of India }\end{array}$ & Plane table & $\begin{array}{l}\text { This study mapped Hispar and its } \\
\text { tributary glaciers on a scale of } 1 \\
\text { inch to } 1 \text { mile }\end{array}$ \\
\hline Visser (1934) & $\begin{array}{l}\text { Karakoram } \\
\text { and } \\
\text { Turkistan }\end{array}$ & $\begin{array}{l}\text { Khan Afraz } \\
\text { Gul Khan, } \\
\text { Muhammad } \\
\text { Akram }\end{array}$ & Plane table & $\begin{array}{l}\text { Topographic map was prepared } \\
\text { at 1:500,000 scale with } 1000 \mathrm{ft} \\
\text { contour interval }\end{array}$ \\
\hline $\begin{array}{l}\text { Shipton et al. } \\
\text { (1938) }\end{array}$ & Shaksgam & $\begin{array}{l}\text { Eric Shipton, } \\
\text { Michael Spender, } \\
\text { J.B. Auden }\end{array}$ & $\begin{array}{l}\text { Watts-Leica } \\
\text { phototheodolite, } \\
\text { subtense-bar } \\
\text { and plane table, } \\
\text { telescopic alidade, } \\
\text { level, plumb-bob, } \\
\text { box-compass, slide } \\
\text { rule }\end{array}$ & $\begin{array}{l}\text { This study mapped more than a } \\
\text { dozen glaciers such as Baltoro, } \\
\text { Sarpo Laggo, Nobande Sobande, } \\
\text { Panmah, Biafo, Trango, Uli Biaho, } \\
\text { Braldu, Choktoi, Cornice, Hoh } \\
\text { Lungma, Sosbon, Virjerab, and } \\
\text { Hispar, using plane table and } \\
\text { phototheodolite at 1:250,000 scale }\end{array}$ \\
\hline Mott (1950) & $\begin{array}{l}\text { Karakoram } \\
\text { Himalayas }\end{array}$ & $\begin{array}{l}\text { Shipton, Fazal } \\
\text { Ellahi and Inayat } \\
\text { Khan from } \\
\text { Survey of India }\end{array}$ & $\begin{array}{l}\text { Zeiss TAL } \\
\text { phototheodolite }\end{array}$ & $\begin{array}{l}\text { The Panmah, Choktoi and } \\
\text { Nobande Sobande Glaciers were } \\
\text { surveyed by Shipton, using the } \\
\text { Zeiss TAL photo-theodolite; } \\
\text { he introduced in India the single } \\
\text { picture method of photographic } \\
\text { mapping during his survey }\end{array}$ \\
\hline
\end{tabular}

glaciers were mapped more than once on a large scale between 1952 and 1996 (Østrem and Haakansen, 1999).

\section{Glacier mapping using remote sensing and GIS}

\section{Manual delineation}

As discussed earlier, topographic glacial mapping based on plane-table and terrestrial photogrammetry required an enormous human and time investment. In comparison, remote sensing data facilitates rapid glacier mapping as fieldwork is only necessary for ground truthing and to obtain ground control points. Initial glacier inventory studies using remote sensing, such as by Williams (1986) and Hall et al. (1992), started in Iceland and Austria, respectively, with the manual digitization of glacier boundaries on standard false colour composites (FCC) of Landsat MSS and TM images. This method is timeconsuming for larger areas, and its accuracy depends on the efficiency of identification 
and recognition of glacier terrain features on satellite imageries.

In India, almost all the glacier inventories based on satellite imageries have been carried out by manual delineation (Table 3 ). These studies used FCC of coarse-resolution satellite data (eg, MSS and LISS I) to highresolution data (eg, LISS IV and PAN), and SOI topographic maps whose scale ranged from 1:250,000 to 1:50,000. Few inventories based on remote sensing and topographical maps included cartographic errors in their studies. In the early 1990s, the Space Application Centre (SAC) completed a glacier inventory programme for the entire Indian Himalayas at a scale of 1:250,000 (Bahuguna, 2008).

\section{Automated glacier mapping}

Automated mapping of glaciers involves image processing techniques on multispectral data such as simple band mathematics and

Table 3 Details of satellite data used in glacier mapping studies of the Indian Himalayas

\begin{tabular}{|c|c|c|c|c|}
\hline Authors & Location & $\begin{array}{l}\text { Satellite data/map and } \\
\text { spatial resolution/scale }\end{array}$ & $\begin{array}{l}\text { Quantification of } \\
\text { cartographic errors }\end{array}$ & Brief description \\
\hline $\begin{array}{l}\text { Dhanju and } \\
\text { Buch (1989) }\end{array}$ & $\begin{array}{l}\text { Parbati-Spiti } \\
\text { basin }\end{array}$ & Landsat TM-30 m & Not mentioned & $\begin{array}{l}\text { This study used FCC of } \\
\text { bands } 2,3 \text { and } 4 \text { for the } \\
\text { manual delineation of } \\
\text { glaciers }\end{array}$ \\
\hline Kulkarni (1991) & $\begin{array}{l}\text { Himachal } \\
\text { Himalayas }\end{array}$ & $\begin{array}{l}\text { Landsat TM-30 m } \\
\text { IRS LISS-II-36.5 m }\end{array}$ & Not mentioned & $\begin{array}{l}\text { This study manually } \\
\text { delineated } 125 \text { glaciers } \\
\text { using FCC (bands } 2,3 \\
\text { and } 4 \text { ) of satellite image }\end{array}$ \\
\hline $\begin{array}{l}\text { Kulkarni et al. } \\
\text { (1999) }\end{array}$ & Satluj basin & $\begin{array}{l}\text { Landsat TM-30 m } \\
\text { IRS LISS-II-36.5 m }\end{array}$ & Not mentioned & $\begin{array}{l}\text { For the additional altitude } \\
\text { information this study } \\
\text { used SOI topographical } \\
\text { maps. In this inventory, } \\
\text { the Himalayan Glacier } \\
\text { Information System } \\
\text { (HGIS) was developed } \\
\text { using dBase III program }\end{array}$ \\
\hline $\begin{array}{l}\text { Dobhal and } \\
\text { Kumar (1996) }\end{array}$ & $\begin{array}{l}\text { Himachal } \\
\text { Himalayas }\end{array}$ & $\begin{array}{l}\text { SOI topographical } \\
\text { maps }(1: 250,000) \\
\text { Landsat TM-30 m }\end{array}$ & Not mentioned & $\begin{array}{l}\text { This study mapped } \\
\text { glaciers of the entire } \\
\text { Himachal Himalayas } \\
\text { except the NE part of the } \\
\text { Spiti basin, which was } \\
\text { omitted due to strategic } \\
\text { importance and restricted } \\
\text { nature }\end{array}$ \\
\hline $\begin{array}{l}\text { Kulkarni and } \\
\text { Suja (2003) }\end{array}$ & Baspa basin & IRS LISS III-23.5 m & Not mentioned & $\begin{array}{l}\text { This study mapped } \\
19 \text { out of } 30 \text { glaciers } \\
\text { in Baspa basin. In this } \\
\text { study, authors did not } \\
\text { include hanging glaciers, } \\
\text { permanent snowfields and } \\
\text { rock glaciers }\end{array}$ \\
\hline
\end{tabular}


Table 3 Continued

\begin{tabular}{|c|c|c|c|c|}
\hline Authors & Location & $\begin{array}{l}\text { Satellite data/map and } \\
\text { spatial resolution/scale }\end{array}$ & $\begin{array}{l}\text { Quantification of } \\
\text { cartographic errors }\end{array}$ & Brief description \\
\hline $\begin{array}{l}\text { Dobhal et al. } \\
\text { (2004) }\end{array}$ & $\begin{array}{l}\text { Dokriani } \\
\text { Glacier }\end{array}$ & $\begin{array}{l}\text { SOI topographical } \\
\text { glacial map }(1: 10,000)\end{array}$ & Not mentioned & $\begin{array}{l}\text { This study estimated } \\
\text { ice volume change and } \\
\text { recession rate of the } \\
\text { Dokriani Glacier }\end{array}$ \\
\hline $\begin{array}{l}\text { Kulkarni et al. } \\
(2005)\end{array}$ & Parbati basin & $\begin{array}{l}\text { SOI topographical map } \\
(1: 50,000) \\
\text { Landsat TM-30 m } \\
\text { IRS LISS-III-23.5 m } \\
\text { IRS PAN-5.8 m }\end{array}$ & Not mentioned & $\begin{array}{l}\text { This study manually } \\
\text { delineated Parbati Glacier } \\
\text { on various temporal } \\
\text { satellite images }\end{array}$ \\
\hline $\begin{array}{l}\text { Kulkarni et al. } \\
\text { (2007) }\end{array}$ & $\begin{array}{l}\text { Himachal } \\
\text { Himalayas }\end{array}$ & $\begin{array}{l}\text { SOI topographical map } \\
(1: 50,000) \\
\text { Landsat TM-30 m } \\
\text { IRS LISS-III- } 23.5 \mathrm{~m} \\
\text { IRS LISS-IV-5 m }\end{array}$ & Not mentioned & $\begin{array}{l}\text { This study manually } \\
\text { delineated } 466 \text { glaciers } \\
\text { of Chenab, Parbati } \\
\text { and Baspa basin of the } \\
\text { Himachal area }\end{array}$ \\
\hline $\begin{array}{l}\text { Berthier et al. } \\
\text { (2007) }\end{array}$ & $\begin{array}{l}\text { Spiti/Lahaul } \\
\text { region }\end{array}$ & ASTER-15 m & \pm 2 pixels $(30 \mathrm{~m})$ & $\begin{array}{l}\text { This study used manually } \\
\text { delineated glacier } \\
\text { boundaries for mass } \\
\text { balance estimation }\end{array}$ \\
\hline Krishna (2005) & $\begin{array}{l}\text { Tista basin, } \\
\text { Sikkim } \\
\text { Himalayas }\end{array}$ & $\begin{array}{l}\text { LISSI, LISSII and } \\
\text { LISSIII satellite data } \\
\text { of IRS }\end{array}$ & Not mentioned & $\begin{array}{l}\text { This study used automatic } \\
\text { NDSI technique for } \\
\text { mapping of snowcover }\end{array}$ \\
\hline $\begin{array}{l}\text { Philip and } \\
\text { Ravindran } \\
(1998)\end{array}$ & $\begin{array}{l}\text { Upper } \\
\text { Bhagirathi } \\
\text { basin }\end{array}$ & Landsat TM-30 m & Not mentioned & $\begin{array}{l}\text { This study mapped } \\
\text { landforms of Gangotri } \\
\text { Glacier using Landsat } \\
\text { TM and concluded that } \\
\text { FCC of bands } 4,5 \text { and } \\
7 \text { are suitable for glacier } \\
\text { mapping }\end{array}$ \\
\hline
\end{tabular}

classification. Automated mapping of snow and ice is based on the fact that snow exhibits high reflectance in the visible and nearinfrared region (VIS and NIR) as compared to short-wave infrared (SWIR) region of the solar spectrum. Bayr et al. (1994) and Rott (1994) proposed thresholds of a ratio image of TM-4 to TM-5 (NIR/SWIR) and TM-3 to TM-5 (RED/SWIR) ratio bands to delineate glacier ice area. Paul (2001) evaluated both ratio image techniques and concluded that the TM-4 to TM-5 ratio technique is the more appropriate for clean-ice glacier mapping. The ratio RED/SWIR performs better in areas with dark shadow and thin debris cover (Paul and Kääb, 2005; Andreassen et al., 2008). A number of inventories used simple and robust ratio methods (Paul et al., 2001; Bolch, 2007; Andreassen et al., 2008). Hall et al. (1995) proposed the Normalized Difference Snow Index (NDSI, [VIS - SWIR] / [VIS + SWIR]) technique for identification of snow. Racoviteanu et al. (2008a) successfully used the NDSI for glacier mapping of Cordillera Blanca. Sidjak and Wheate (1999) obtained best results using a combination of principal components two, three and four of the masked glacier area, the ratio TM-4/TM-5, and the NDSI. However, semi-automatic methods failed in the accurate mapping 
of debris cover due to a similar spectral signature of surrounding bedrock.

In the Indian Himalayas, few studies have been carried out with automatic glacier mapping techniques. Racoviteanu et al. (2008b) used the NDSI method for mapping glaciers of the Sikkim Himalayan region. Gupta et al. (2005) mapped dry/wet snowcover in the upper Bhagirathi basin (Gangotri Glacier) using the NDSI technique on digital IRSLISS-III multispectral data. Kaushal et al. (2004) used the ratio of IRS LISS III band 4 (SWIR band) and band 3 (Red band) for snow mapping in Siachen Glacier area using IRS LISS data. Philip and Sah (2004) used merged IRS ID LISS III and PAN product for the study of glacier landform mapping of the Shaune Garang Glacier. The results of these studies indicate that these methods are useful for clean-ice glacier delineation/detection, but when used for debris-covered glaciers the results are not very encouraging. This is confirmed in Figure 4, where NDSI $(1-4 / 1+4)$ and different band combinations for the ratio method ( $1 / 3$ and $3 / 4$ band) on ASTER images were used for glacier mapping of the Garhwal Himalayas. The observations are summarized as follows:

(1) NDSI and Band ratio method could not differentiate the extent of debris-covered glacier ice, as a result of the similar spectral signature from the surrounding debris;

(2) NDSI and Band ratio VIS/NIR misclassified proglacier lakes in threshold glacier areas, whereas Band ratio NIR/
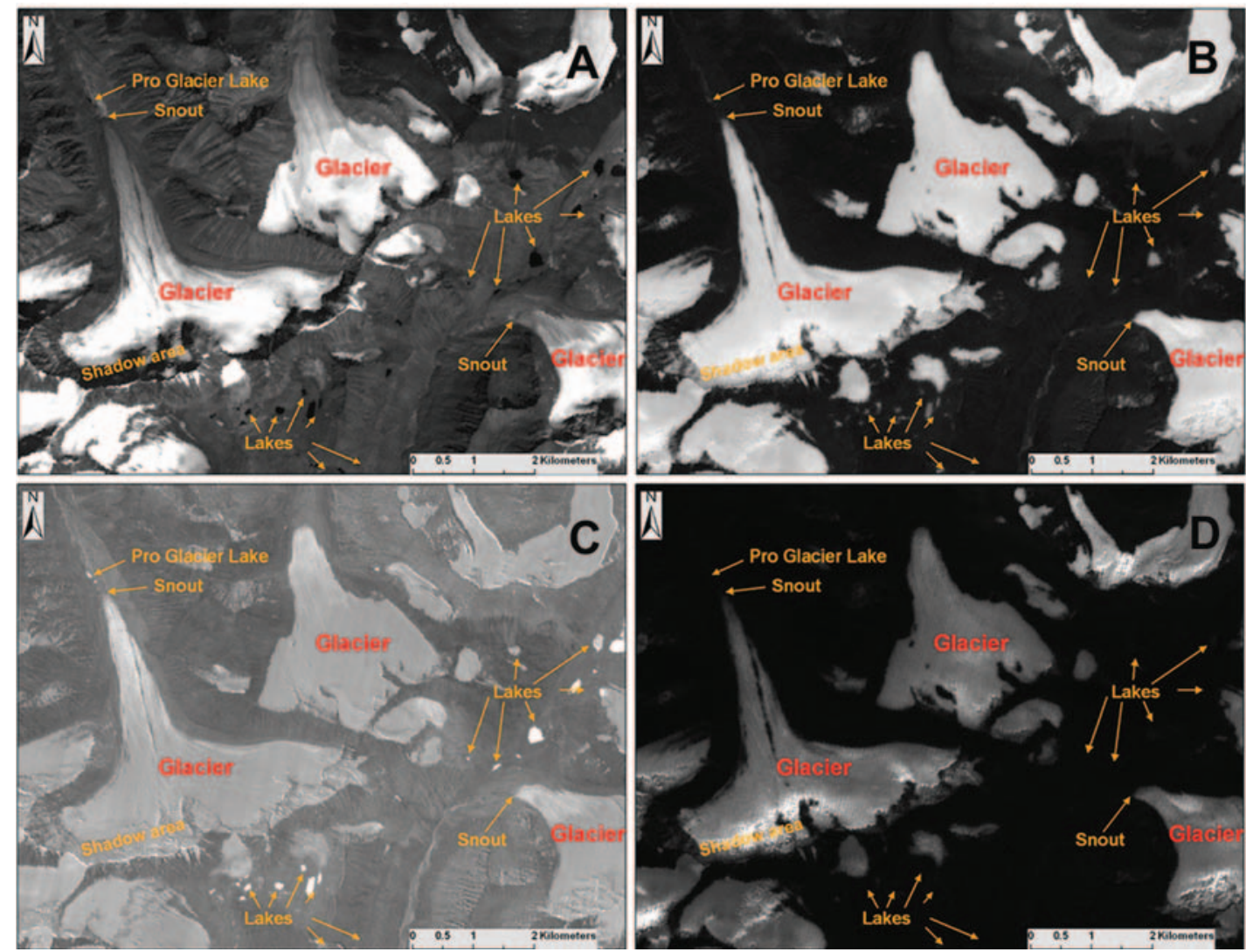

Figure 4 (A) Band 3 of ASTER image of the Garhwal Himalayas (2006). (B) NDSI image $(1-4 / 1+4)$. (C) Band ratio (1/3). (D) Band ratio (3/4) 
SWIR classified only clean glacier ice, therefore Band ratio NIR/SWIR is a more appropriate method for clean glacier ice than NDSI;

(3) in addition, Band ratio NIR/SWIR performs better than NDSI in the case of shadow areas.

\section{Mapping of debris-covered glaciers}

As illustrated above, clean-ice glaciers can be mapped automatically using multispectral images. However, many glaciers in the Himalayas are characteristically covered with thick debris mainly due to large volumes of debris-laden ice avalanche and rockfall on glacier surface from steep surrounding slopes (Shroder et al., 2000). Several studies have shown the applicability of morphometric parameters derived from DEM and thermal band in the mapping of debris-covered glaciers. Ranzi et al. (2004) used thermal signature from ASTER and Landsat imagery for debris-covered glacier mapping. This method is based on the fact that the surface temperatures of the debris layer superimposed on a glacier's ice is cooler than on the surroundings without ice. However, this is limited to debris layers thinner than 40-50 cm. Bishop et al. (2001) successfully showed that morphometric parameters such as slope, plan and profile curvature help to differentiate debris-covered glaciers from surrounding moraines. Paul et al. (2004) presented a semi-automatic method for delineation of debris-covered glaciers in the Swiss Alps, which combines multispectral image classification (glacier ice, vegetation) with DEM data (24-degree slope), neighbourhood analysis (connection to glacier ice), and change detection. Bolch and Kamp (2006) proposed a simple morphometric glacier mapping approach (MGM) based on plan curvature and profile curvature. Bolch et al. (2007) presented an automated but complex morphometric-based approach to outline the debris-covered glaciers of the Mt Everest Area (Nepalese Himalayas) based on the altitude, slope, plan and profile curvature derived from ASTER DEM as well as thermal bands of ASTER. Thus, all the proposed methods are region-specific, not universally established, and are optimized only for a small region. The suitability of ASTER DEMs has been established, but the results seem to be feasible for larger valley glaciers $\left(>1 \mathrm{~km}^{2}\right)$ with well-defined lateral moraines.

In the Himachal Himalayas, Kulkarni et al. (2005; 2007) manually delineated debris-covered glaciers using IRS satellite data (Table 3). These studies assumed that grass cover seen in the months of August and September on terminal moraine can be used as a clue to delineate debriscovered glaciers. However, this technique failed in the case of the heavily debriscovered Chaurabari Glacier. During fieldwork in the months of August and September 2006 we observed that the terminal moraine near ablation zone was devoid of any vegetation.

We tested the applicability of the morphometric approaches in the Himalayan region and generated an ASTER DEM for the Garhwal Himalayas at $30 \mathrm{~m}$ spatial resolution using 11 GCPs derived from SOI topographical map and 129 TPs for image matching with 0.7 pixel RMS errors. Morphometric parameters such as slope, aspect, plan and profile curvature map were generated using SAGA. These parameters help to delineate the snout of Gangotri Glacier. This method is potentially suitable for mapping of debris covered-snout of Gangotri Glacier (Bhambri et al., unpublished data).

\section{Measurement of glacier volume changes based on digital elevation models}

\section{Generation of digital elevation models}

Digital elevation models (DEM) are valuable tools for mapping, modelling, analysing and visualizing of glacio-geomorphic phenomena in glacial environment (Etzelmüller and Sollid, 1997; Etzelmüller et al., 2001; Bolch et al., 2005). DEMs play an important role 
in the preparation of ortho-images in high mountain terrain (Finsterwalder, 1984), in estimating glacier hypsometry (Brocklehurst and Whipple, 2004), in the atmospheric correction of satellite imagery (Bishop and Colby, 2002) and in derivative parameter maps such as slope, plan and profile curvature, aspects of which can be further used for debris-covered glacier mapping (section III, 3). Furthermore, DEMs are most important for the estimation of volume change for inaccessible glacier regions (Rignot et al., 2003; Surazakov and Aizen, 2006; Berthier et al., 2007; Schiefer et al., 2007; Bolch et al., 2008).

DEMs can be prepared by different methods, such as space- and airborne optical stereo data, interferrometric SAR (InSAR) data, space and airborne radar and laser alimentary (eg, LiDAR), and topographic maps. The accuracy of the DEM derived from remote sensing depends on several factors, such as spatial resolution of satellite data, positional and vertical accuracy of ground control points (GCPs), and contrast and cloud cover in optical satellite images. GCPs can be computed for DEM generation mainly from three methods: highly precise DGPS measurements during fieldwork; existing rectified topographic maps; and from known satellite positions and rotation angles, where DGPS measurements and topographic maps are not available. This method depends on software capability (Kääb et al., 2003). Berthier et al. (2007) used this method for collection of GCPs in the western Himalayas for the estimation of glacier elevation changes.

Terra ASTER is the most economical optical stereo satellite data on $15 \mathrm{~m}$ spatial resolution, which is the primary source of DEM generation under GLIMS Project (Kargel et al., 2005; Raup et al., 2007). SPOT-5, ALOS PRISM, CartoSat I and II, IKONOS, Quickbird and GeoEye-1 are the other satellites which offer stereo capability and can be used to monitor the glacier surface in three dimensions. Terra ASTER and ALOS PRISM offer along track stereo capability with quasi-simultaneous image acquisition, while the other sensors offer across-track acquisition where the timelag in the acquisition may cause problems (eg, due to clouds, different atmospheric conditions). SPOT 5 and ASTER have the highest coverage area $(\sim 60 \times 60 \mathrm{~km})$ compared with other satellite data.

Less contrast and cloud cover in satellite data can hamper the identification of suitable tie points and can lead to data gaps or elevation inaccuracies in output DEM which in turn can affect the results regarding volume changes. Therefore, it is essential to know elevation inaccuracies using RMS errors in glaciated regions based on existing highly precise DEMs and fieldwork. DGPS, GPS readings and more details about accuracy assessments in glaciated terrain are described in Table 4.

\section{Deriving glacier volume changes and glacier} mass balance

Literature survey reveals that estimations of glacier volume are mostly based on the area using: (1) volume/area scaling (Chen and Ohmura, 1990; Bahr, 1997); and (2) the AAR/ELA method (Kulkarni, 1992; Rabatel et al., 2005). Kulkarni et al. (2004) estimated the mass balance of 19 glaciers in the Baspa basin, Himachal Pradesh, using the accumulation area ratio (AAR) method. This method utilizes a regression equation between AAR and specific mass balance, derived from unpublished field data collected by the Geological Survey of India during 1982-88 for Shaune Garang Glacier, and 1976-84 for Gor Garang Glacier. The AAR for 2000 and 2001, obtained by systematic weekly analysis of WiFS images from the IRS satellite from May to September, has also been estimated. Field measurement is frequently required for direct monitoring of traditional mass balance calculation. This method, like any other detailed field survey, is time-consuming and poses the potential risk of long stays in rugged and 


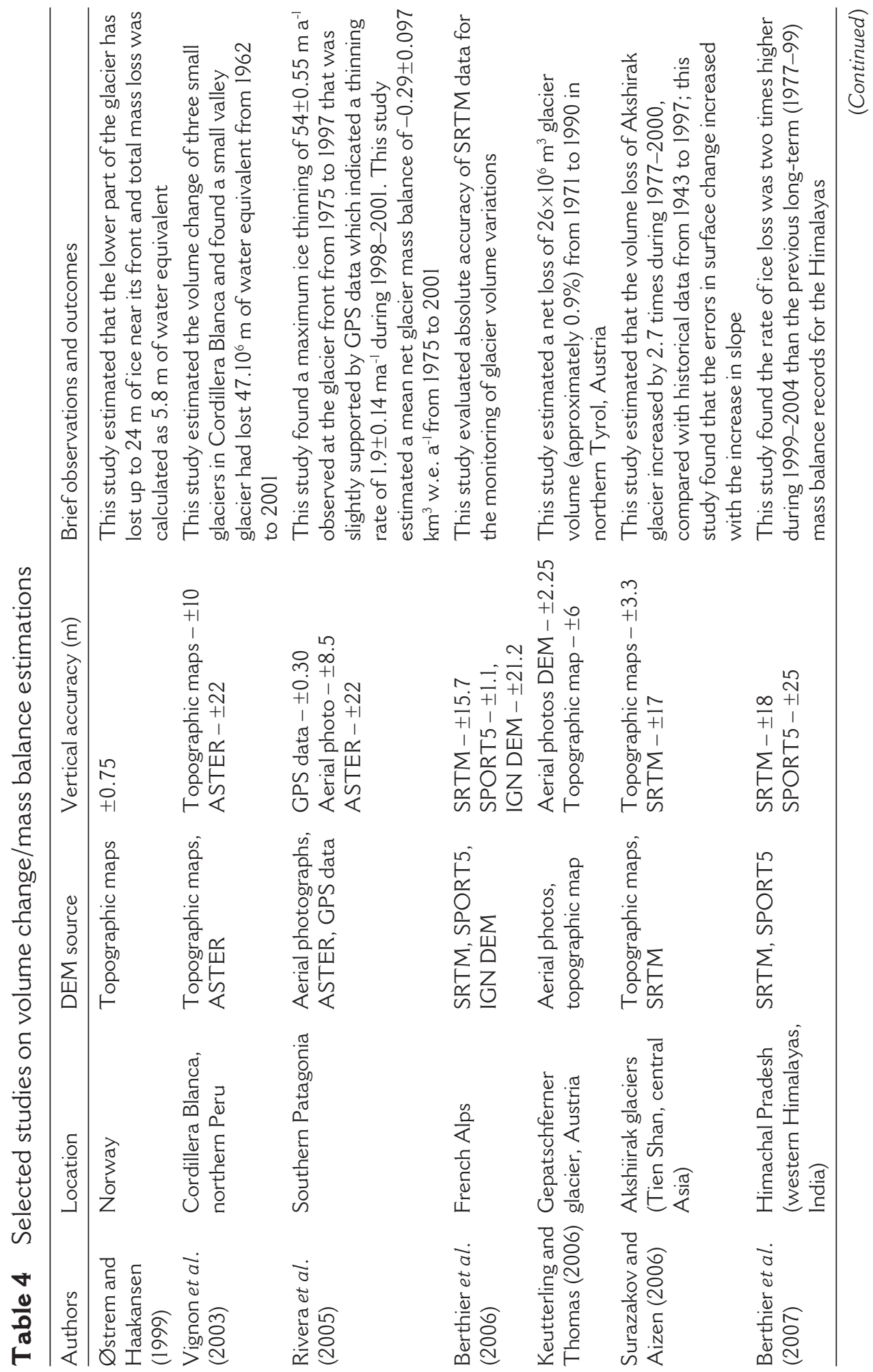




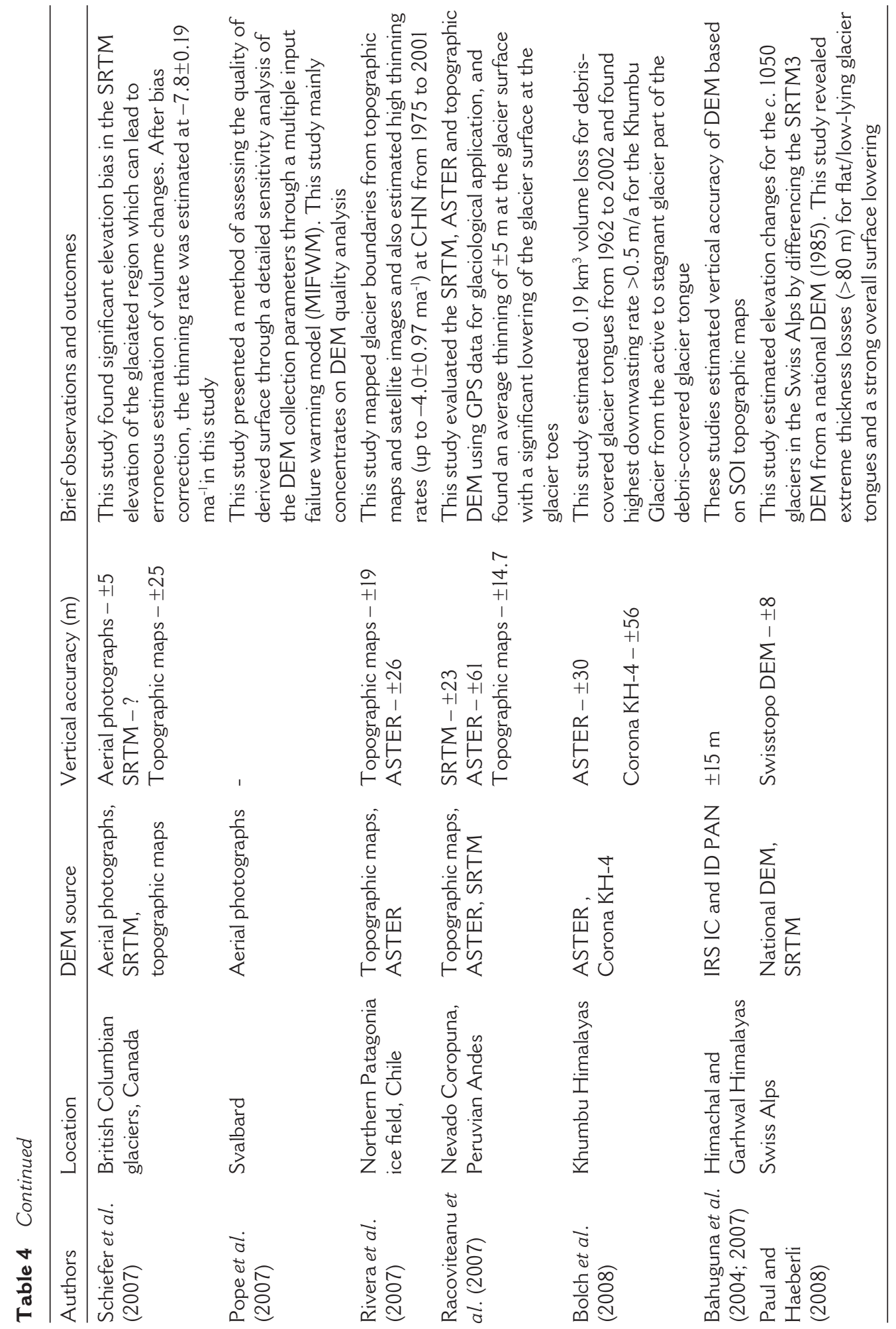


extreme weather conditions, which in turn has financial implications. Hence, surface changes derived from DEMs, known as indirect geodetic methods, could be a useful tool to calculate the glacier volume changes and mass balance estimation (Etzelmüller and Sollid, 1997). This method is based on the assumption that a change in elevation (dh/dr) over time from DEM constructed over the glacier region from various sources (section IV, l) can be translated into a change in mass. This method holds true if: (1) there is no change in elevation on the bedrock due to neo-tectonic activities; and (2) the density of ice mass has not changed (Bamber and Rivera, 2007). However, the accuracy of mass balance and volume change estimation derived from geodetic method is governed by several factors, such as:

(1) error generation during DEM generation using optical stereo satellite data due to saturation of pixels, shadow areas, low contrast in imageries;

(2) error in DEM generation using radar data due to radar shadow, foreshortening, layover, and penetrating into snow;

(3) error generation from scanning of old topographic maps and digitization of contours and interpolation for conversion of digitized contours into surface (pixels);

(4) error generation during ellipsoid and datum conversion for subtraction of different DEM derived from various sources;

(5) error generation during changes in spatial resolution for the subtraction of various DEMs;

(6) errors occurring from assumption of constant value for loss and gain of density of ice/firm;

(7) error generation during rectification of old topographic maps and satellite images.

Thus, the accuracy of volume change/mass balance estimation depends on the accuracy of the DEMs generated from various sources. Aerial photographs and most topographic maps of the Indian Himalayas are not in the public domain. Therefore, the subsequent reference DEMs cannot be generated. To date, only one study has been published (Berthier et al., 2007) for the mass balance estimation of the Himachal Himalayas using SRTM and SPOT-5 satellite data (Table 4).

\section{Challenges in comparing data sets from different sources}

Different data sets obtained at different times have inherent differences in resolution, reference system, interpretation bias and the classification techniques adopted. However, recent developments in geo-informatic software facilitate rectification, reprojection, and error detection and allow analysis of these potential error sources. Nevertheless, results of different studies in similar regions do not always match, and thus induce uncertainty in the scientific understanding of the problem. Creation of metadata is being promoted to facilitate the reinterpretation of the data sets by other users.

Topography maps published by the SOI generated from aerial photographs have serious accuracy issues, specifically in the case of ice-covered (Vohra, 1980) and debriscovered glaciers. This is attributed mainly to cartography skills and the time of aerial photography acquisition during early winter months after snowfall (Agarwal, 2001). A review of the history sheets for 12 topographic maps of Himachal Pradesh also shows that 10 topographic maps were prepared from aerial photographs taken in November/December (Table 5). The timing of aerial photography makes it very difficult for even a skilled image interpreter to distinguish the snout from the surrounding moraines which can result in errors in the delineation of glacier outlines.

Vohra (1980) found differences in the length of the debris-covered Gara Glacier based on the SOI topographic map and field investigation. The length of the clean-ice segment of Gara Glacier has been reported to be $5.5 \mathrm{~km}$. Well-developed terminal moraines beyond the debris-covered glacier segment were falsely interpreted and indicate a length 
Table 5 Details of aerial photographs used in the preparation of topographic maps of Himachal Pradesh

\begin{tabular}{|c|c|c|c|c|}
\hline \multirow{2}{*}{$\begin{array}{l}\text { Topographic map } \\
\text { number }\end{array}$} & \multirow{2}{*}{$\begin{array}{l}\text { Date of aerial } \\
\text { photography }\end{array}$} & \multicolumn{2}{|c|}{ Scale } & \multirow[t]{2}{*}{ Publication year } \\
\hline & & Topographic map & Aerial photo & \\
\hline $53 \mathrm{E} / 9 / \mathrm{NE}$ & Nov/Dec 1975 & $1: 25,000$ & $1: 50,000$ & 2002 \\
\hline $53 \mathrm{E} / 9 / \mathrm{SE}$ & 28 Nov 1975 & & & \\
\hline $53 \mathrm{E} / 9 / \mathrm{NW}$ & Nov/Dec 1975 & & & \\
\hline $53 \mathrm{E} / 13 / \mathrm{NW}$ & Nov/Dec 1975 & & & \\
\hline $53 \mathrm{E} / 13 / \mathrm{SW}$ & 28 Nov 1975 & & & \\
\hline $53 \mathrm{E} / 10 / \mathrm{NW}$ & Nov/Dec 1975 & & & \\
\hline $53 \mathrm{E} / 10 / \mathrm{SW}$ & 11 Dec 1975 & & & \\
\hline $53 \mathrm{E} / 10 / \mathrm{SE}$ & 11 Dec 1975 & & & \\
\hline $53 \mathrm{E} / 10 / \mathrm{NE}$ & 11 Dec 1975 & & & \\
\hline $53 \mathrm{E} / 05$ & June 1960 & $1: 50,000$ & $1: 70,000$ & 1968 \\
\hline $53 \mathrm{E} / 09$ & 08 June 1962 & & $1: 60,000$ & \\
\hline $53 \mathrm{E} / 13$ & March 1962 & & & \\
\hline
\end{tabular}

of $7 \mathrm{~km}$, amounting to an increase of $27.3 \%$ in length. Basically, it can be difficult for cartographers to distinguish the actual debriscovered glacier terminus, which results in misclassification of well-developed terminal moraines as glacier boundaries. Agarwal (2001) reported significant differences in aerial extent of Gor Garang and Shaune Garang Glaciers in the GSI unpublished reports. Glacier outlines derived from topographic maps suggest an area almost twice as great as that of field survey glacier map outlines (Table 6). Mukherjee and Sangewar (2001) used the sketch of the Gangotri Glacier snout prepared by Griesbach in 1889, the SOI topographical map (1962), SPOT imagery and vertical aerial photographs for a Gangotri Glacier recession study. They calculated an advance of the snout of about $500 \mathrm{~m}$ until 1935 with respect to the position in 1889, whereas Sharma and Owen (1996) and Naithani et al. (2001) indicate that the Gangotri Glacier has been retreating since 1780. It is noteworthy that the sketch prepared by Griesbach could not be overlain accurately, as it is a rough sketch map of the 1889 situation while the other was produced by modern photogrammetric methods with limited fieldwork.

The debris-covered Chaurabari Glacier is the source of the Mandakani River in the Garhwal Himalayas. The glacier outline of the Chaurabari Glacier derived from the 1962 SOI topographic map does not clearly show the boundary of the glacier, nor of its companion glacier (Srivastava et al., 1995). Our own investigations based on Landsat MSS, TM, ETM+ and Terra ASTER satellite images from the years 1972, 1990, 1999, 2003 and 2006 indicate that the Chaurabari Glacier has one companion glacier which flows from the northwest (Figure 5). We overlaid the 1962 glacier outline on Landsat MSS (1972) and ASTER (2006) satellite images, which indicated a shift in the ice divide and cliff face. A rocky cliff is a rigid geomorphic feature which can be assumed not to shift within the very short timespan, geologically speaking. This overlay operation implies a mapping error in the delineation of glacio-geomorphic features of the Chaurabari Glacier in the SOI maps.

On the basis of modified map of Auden, Srivastava (2004) estimated a $0.58 \mathrm{~km}^{2}$ area 
Table 6 Area difference in Gor Garang and Shaune Garang Glaciers in topographic map and field survey (from Agarwal, 2001)

\begin{tabular}{lll}
\hline Glacier name & \multicolumn{2}{c}{ Area $\left(\mathrm{km}^{2}\right)$} \\
\cline { 2 - 3 } & Topographical map SOI & Field survey \\
\hline Gor Garang & 4.33 & 2.02 \\
Shaune Garang & 8.12 & 4.94 \\
\hline
\end{tabular}

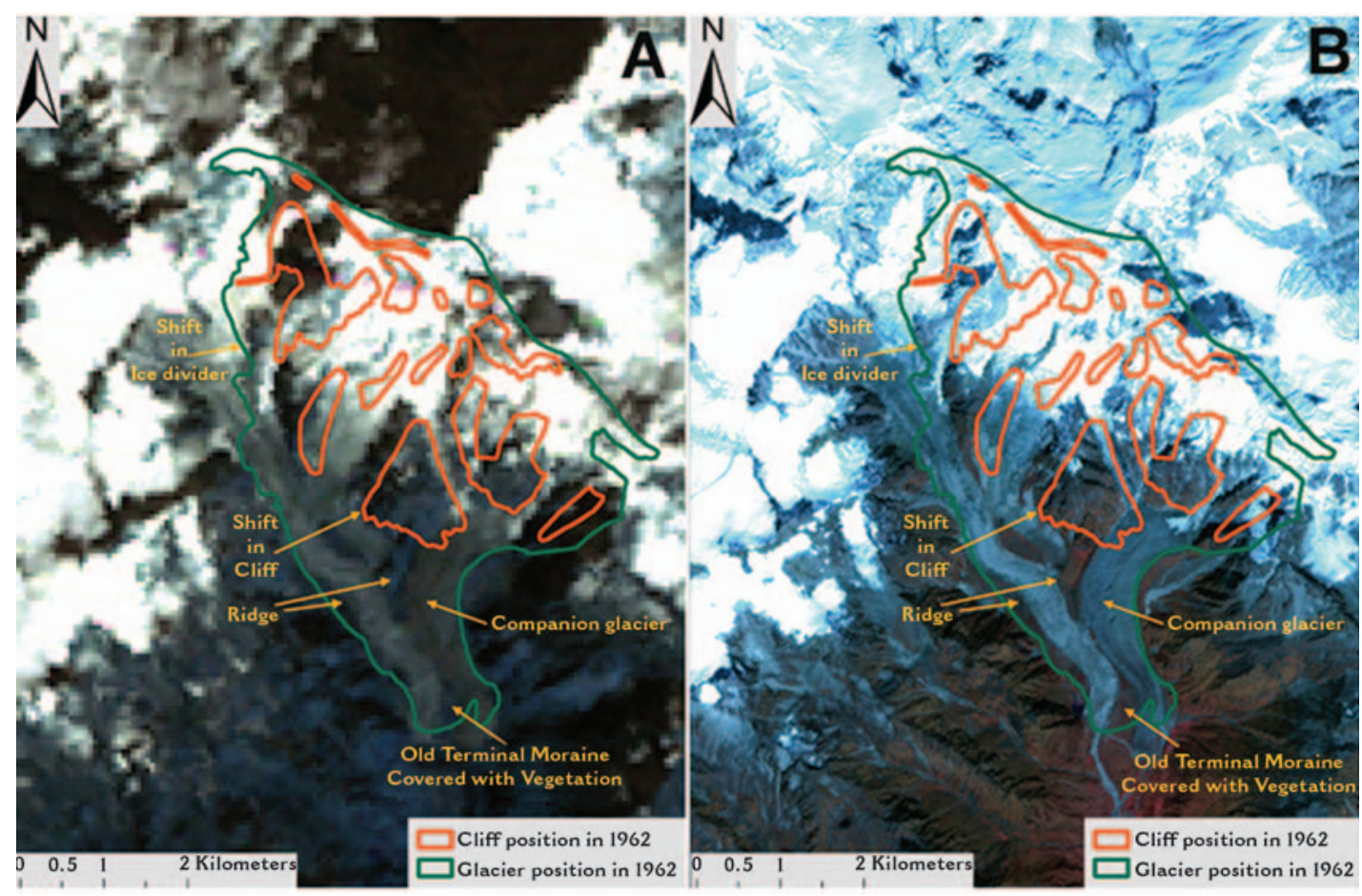

Figure 5 Overlay of glacier and cliff outlines from topographic map on different years' satellite images. (A) 1972 MSS FCC image. (B) 2006 ASTER FCC image

loss of ice on the Gangotri Glacier from 1935 to 1996 whereas Ahmad and Hasnain (2004) estimated a 20 times greater loss $\left(10 \mathrm{~km}^{2}\right)$ at this glacier from 1985 to 2001 based on topographic map and satellite image (Table 7). The area of Gangotri Glacier calculated by Sharma and Owen (1996) and Ahmad and Hasnain (2004) does not accord well with the GSI studies by Srivastava (2004) and Dutta et al. (2004) (Table 7).

Kulkarni et al. (2005) calculated a $48.44 \mathrm{~km}^{2}$ area of the Parbati Glacier based on the SOI topographic map nos. $53 \mathrm{E} / 9$ and 13 (1962), and $40.14 \mathrm{~km}^{2}$ from a 1990 satellite image, which reveal that the area loss amounted to $8.3 \mathrm{~km}^{2}$ in 28 years. Fortunately, the SOI produced a revised topographic map nos. 53E/9 and 13 from surveys done in 1987 and published in 2002. These maps are available at the scale of both 1:50,000 and $1: 25,000$. For this study, these topographic maps were registered with RMS errors of $1.8 \mathrm{~m}(1: 25,000)$ and $3.7 \mathrm{~m}(1: 50,000)$. The area of the Parbati Glacier was calculated 
Table 7 Area of Gangotri Glacier estimated by various Indian scientists and organizations

\begin{tabular}{lll}
\hline Authors & Area $\left(\mathrm{km}^{2}\right)$ & Mapping reference \\
\hline Sharma and Owen (1996) & 87.08 & Huber topographic map $(1: 150,000)$ \\
Ahmad and Hasnain (2004) & 87 & Survey of India topographic map 1985 \\
Ahmad and Hasnain (2004) & 77 & IRS Pan Image, 2001 \\
Srivastava (2004), GSI & 143.58 & Topographic map 1966 (1st edition), SOI \\
& & with fieldwork modification \\
\hline
\end{tabular}

Table 8 Area and length parameters of Parbati Glacier

\begin{tabular}{|c|c|c|c|c|}
\hline Authors & Area $\left(\mathrm{km}^{2}\right)$ & Mapping reference & Length (m) & Scale \\
\hline Kulkarni et al. (2005) & 48.44 & $\begin{array}{l}\text { SOI topographic map } 1962 \\
\text { surveyed }\end{array}$ & 16,689 & $1: 50,000$ \\
\hline Kulkarni et al. (2005) & 40.14 & 1990 satellite image & 10,698 & - \\
\hline Present study & 44.78 & $\begin{array}{l}\text { SOI topographic map } 1987 \\
\text { surveyed }\end{array}$ & 12,672 & $1: 50,000$ \\
\hline Present study & 44.68 & $\begin{array}{l}\text { SOI topographic map } 1987 \\
\text { surveyed }\end{array}$ & 12,499 & $1: 25,000$ \\
\hline
\end{tabular}

at $44.78 \mathrm{~km}^{2}$ and $44.68 \mathrm{~km}^{2}$ for the scales of $1: 50,000$ and $1: 25,000$, respectively. This indicates an area of $0.1 \mathrm{~km}^{2}$ less in the map having a scale of $1: 25,000$ in comparison to the 1:50,000 scale map. In addition, the ice-covered area diminished by $3.66 \mathrm{~km}^{2}$ in 25 years on the basis of 1962 and 1987 topographic maps (Table 8). A comparison of the calculated area of the Parbati Glacier based on a 1990 satellite image (Kulkarni et al., 2005) with the area calculated based on the 1987 topographic map reveals that an area of $4.64 \mathrm{~km}^{2}$ was cleared of ice in three years - a rather unrealistic value.

In order to assess the positional accuracy of the Parbati Glacier region maps (53E/13 and $53 \mathrm{E} / 13 / \mathrm{SW}$ ) at the scales of $1: 50,000$ and 1:25,000 (1987 surveys), we used 50 common location points such as river junctions, road junctions and spot heights in both maps. We found a horizontal shift of $64 \mathrm{~m}$ on the map at a scale of 1:50,000, as compared to the $1: 25,000$ scale map. An overlay operation of the glacier outline of both maps confirmed the planimetric shift, with a $179 \mathrm{~m}$ difference in length from both the maps estimated from the central line of the glacier (Table 8).

\section{Glacier variations since the Little Ice Age in the Indian Himalayas}

The Geological Survey of India and other scientific Indian organizations have at their disposal almost 100 years of well-documented recession records of the lengths of selected Garhwal and Lahul Spiti glaciers, such as Gangotri (1842-2006), Meola (1912-2000) and Milam (1906-97) Glaciers. Gangotri, Dokriani and Chotta Shigri Glaciers have been surveyed extensively by several researchers working on mass balance, hydrological, geomorphological, isotopic and glacier recession. The Integrated Centre for Mountain Development (ICIMOD) - Asia Pacific Network organized a glacier inventory study on Himachal Pradesh, Uttarakhand and Sikkim in 2003-2004 (Campbell, 2005). However, this study has not been carried out in Kashmir and Arunachal Pradesh. Recently, the Space Application Centre (SAC) has started glacier change studies 
in 15 subbasins of the Indian Himalayas, particularly: the Alaknanda, Bhagirathi, Dhauliganga, Goriganga and Mandakini (subbasins of the Ganga basin); the Chandra, Bhaga, Miyar, Warwan and Bhut (subbasins of the Chenab basin); the Ravi and Spiti basins in the Himachal Himalayas; the Suru and Zanskar basin in the Kashmir Himalayas; and the Tista basin in the Sikkim Himalayas (Bahuguna, 2008).

A study by Mayewski and Jeschke (1979) indicates that Himalayan glaciers have been receding since 1850 . The length recession records of Himalayan glaciers (Figure 6; Table 9) indicate that glacier retreat is irregular in extent and rate. However, these records have to be used with caution due to the different response time of the glaciers. Overall, the recession of the glacier tongues has accelerated since the 1960s. For instance, in Bhagirathi basin, Dokriani Glacier retreated at the rate of $16.6 \mathrm{~m} / \mathrm{a}$ during 1962 to 1995 , and from 1995 to 2000 it retreated $18.5 \mathrm{~m} / \mathrm{a}$ (Dobhal et al., 2007). Chotta Shigri Glacier in the Chandra basin retreated $27.5 \mathrm{~m} / \mathrm{a}$ from 1962 to 1989 , and $53 \mathrm{~m} / \mathrm{a}$ during 1988 to 2003 (Kulkarni, 2007).

In the Alaknanda basin, the ice-covered area of Satopanth Glacier diminished by $313.9 \mathrm{~m}^{2}(0.0015 \%)$ near the snout from 1962 to 2006, whereas Bhagirathi Kharak Glacier lost an area of $129.4 \mathrm{~m}^{2}(0.0004 \%)$ during a similar time period (Nainwal et al., 2008). These two glaciers are situated in the same basin and likely experienced similar climatic conditions. However, both glaciers are reported to be retreating at different recession rates. Bhagirathi Kharak and Satopanth Glaciers retreated $7.4 \mathrm{~m} / \mathrm{a}$ and $22.8 \mathrm{~m} / \mathrm{a}$ during 1962 to 2006 , respectively. This might be due to uneven distribution of tributary glaciers, active cirques, drainage density and distributions of supraglacial debris cover (Nainwal et al., 2008).

Kulkarni et al. (2007) reported glacial retreat for 466 glaciers in the Chenab, Parbati and Baspa basins (Himachal Himalayas) from 1962 to 2001-2004. This investigation estimated that $21 \%(\sim 0.52 \% / a)$ of the glacier area was deglaciated from 1962 to 2001-2004. The amount of retreat varies between 22\% (Parbati basin) and 19\% (Baspa basin) during the above period. Kulkarni et al. (2007) concluded that the number of glaciers increased between 1962 and 2001 due to disintegration of larger glacier masses. This study suggests that glaciers $<1 \mathrm{~km}^{2}$ lost 38\% ( .095\%/a) of their 1962 area, which reveals that small Himalayan glaciers are retreating at a high rate due to slight or negligible accumulation. Similarly, several studies outside the Himalayas such as in the Swiss Alps suggest that glaciers $<1$ $\mathrm{km}^{2}$ lost $57 \%$ of their area $(\sim 1.48 \% / \mathrm{a})$ during 1973 to 2000 (Zemp et al., 2007). The inner Tien Shan (Terskey Alatoo) glaciers $<1 \mathrm{~km}^{2}$ lost $40 \%$ of their area $(\sim 1.29 \% / \mathrm{a})$ during 1971 to 2002 (Narama et al., 2006). Similar tendencies can be found in many other part of the world, eg, the northern Tien Shan (Bolch, 2007) and western Canada (Bolch et al. 2009). This indicates that small glaciers retreat more rapidly than the larger ones.

Kulkarni (2007) estimated that the average altitude of the snow-line at the end of the ablation season is $5400 \mathrm{~m}$ and $5297 \mathrm{~m}$ for south- and north-facing glaciers, respectively, in Himachal Pradesh. Generally, the combined influence of altitudinal distribution and little or no accumulation zone is likely to be the major cause of the rapid recession of the small glaciers. For example, Nagpo Tokpo Glacier in Spiti subbasin (Satluj basin) is located in the $5240 \mathrm{~m}$ to $5720 \mathrm{~m}$ altitude range. It receded $65 \mathrm{~m} / \mathrm{a}$ during 1963 to 1998. Available fluctuation records of Indian glaciers suggest that, for north- and northeast-facing glaciers in the Bhagirathi basin, such as Gangotri and Meru Glaciers, the recession rate fell after 1990, whereas the Parbati and the Bada Shigri Glaciers are retreating dramatically. Commonly, south-, southeast- and southwest-facing glaciers, such as Jaunder, Jhajju and Tilku Glaciers in the Tons Valley, are receding rapidly at a rate of more than $30 \mathrm{~m} / \mathrm{a}$. These valley 


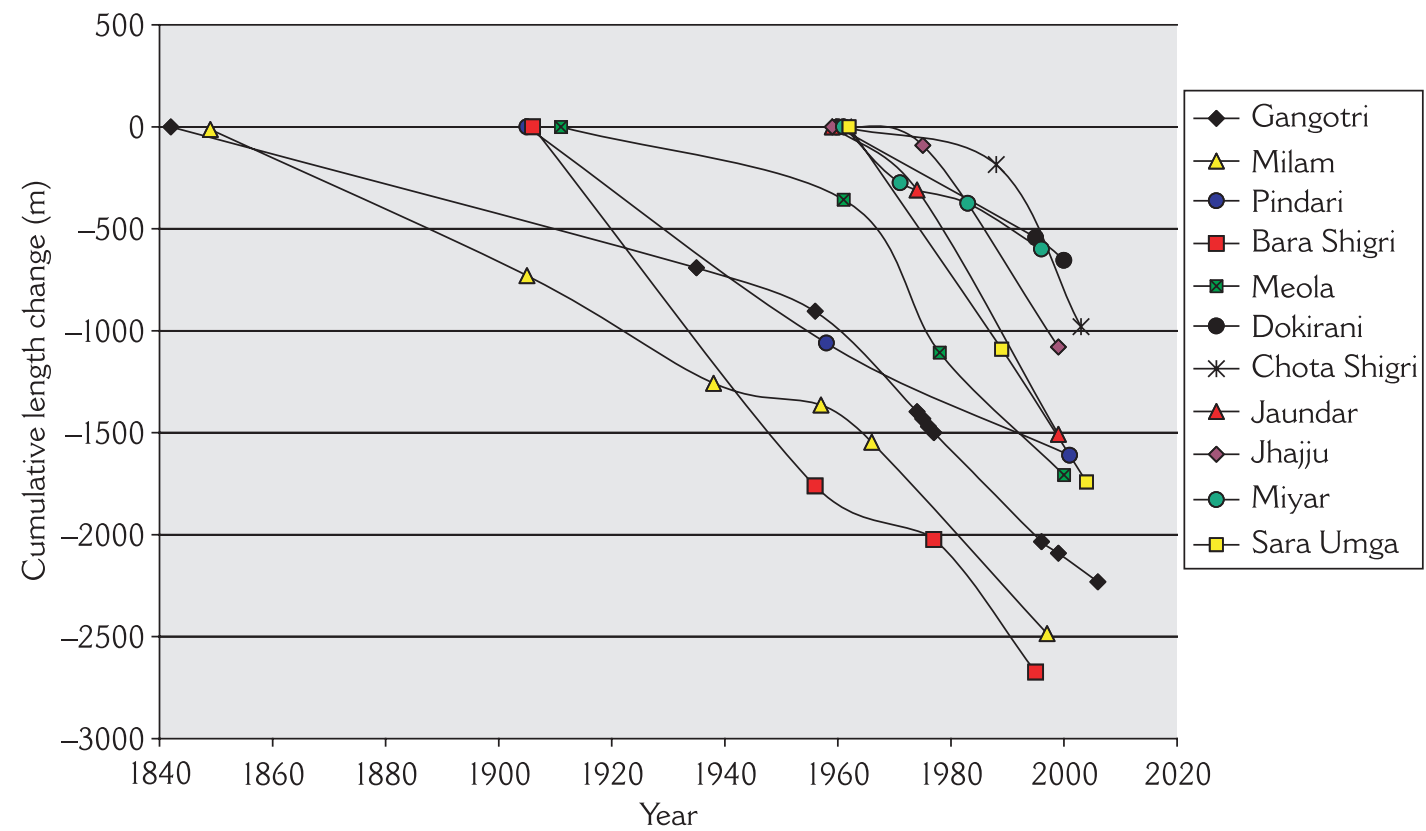

Figure 6 Cumulative length changes of selected Indian Himalayan glaciers; the markers indicate the years of measurements (see Table 9)

glaciers accumulate under the influence of the southwestern monsoon. Published records (Table 9) suggest that glaciers longer than $15 \mathrm{~km}$ retreat at a rate of more than 20 $\mathrm{m} / \mathrm{a}$, except for Miyar and Gangotri Glaciers, and, furthermore, the recession of these glaciers has accelerated compared with the previous observation. These observations suggest glacial retreat in Dauliganga, Gori Ganga basin, such as Jhulang $(11 \mathrm{~m} / \mathrm{a})$ and Burpu Glaciers $(5 \mathrm{~m} / \mathrm{a})$, increasing in the Tons Valley of Yamuna basin, reaching a maximum in the Parbati, Chenab and Baspa basins (Figure 1). Kulkarni et al. (2005) estimated an average recession rate of 173 $\mathrm{m} / \mathrm{a}$ for the Parbati Glacier from 1962 to 2001 and predicted that the main glacier body would continue to retreat at almost the same rate until 2022. Almost $24 \%$ of the area of the Parbati Glacier was deglaciated from 1962 to 2001, whereas Dokriani Glacier lost about $11 \%$ of its previous area in during 1962-95.

The Snow and Avalanche Study Establishment (SASE) have established a network of 50 manned metrological observatories and 40 automatic weather stations in the northwestern Himalayas (Negi et al., 2007). This climatic data could be used for interpretation at micro-level for the fluctuation of particular Indian Himalayan glaciers.

\section{Discussion}

\section{Historical and recent glacier mapping}

Historical glacier mapping in the Himalayas was dependent on risky and time-consuming field investigations involving the use of heavy survey equipment. Today, remote sensing images and techniques facilitate glacier mapping and the investigation of recent glacier fluctuations in less time for remote mountainous areas. In India, however, most studies on glacier mapping delineate glacier outlines using time-consuming on-screen digitization. Automated mapping of clean glacier ice has been successfully attempted on the Sikkim Himalayas and can be applied in other parts of the Himalayas as well 
Table 9 Recession records of selected Himalayan glaciers

\begin{tabular}{|c|c|c|c|c|c|c|c|c|c|}
\hline Glacier & Basin & $\begin{array}{l}\text { Length } \\
(\mathrm{km})\end{array}$ & $\begin{array}{l}\text { Area } \\
\left(\mathrm{km}^{2}\right)\end{array}$ & Orientation & $\begin{array}{l}\text { Snout height } \\
\text { (m a.s.l.) }\end{array}$ & $\begin{array}{l}\text { Snout height } \\
\text { measurement year }\end{array}$ & $\begin{array}{l}\text { Record of } \\
\text { fluctuation in years }\end{array}$ & $\begin{array}{l}\text { Recession } \\
(\mathrm{m} / \mathrm{y})\end{array}$ & References \\
\hline \multirow[t]{9}{*}{ Gangotri } & \multirow[t]{9}{*}{ Bhagirathi } & \multirow[t]{9}{*}{30} & \multirow[t]{9}{*}{143} & \multirow[t]{9}{*}{ NW } & \multirow[t]{9}{*}{3902} & \multirow[t]{9}{*}{1996} & $1842-1935$ & 7.35 & \multirow{9}{*}{$\begin{array}{l}\text { Auden (1937), } \\
\text { Srivastava (2004), } \\
\text { Naithani et al. } \\
\text { (2001), Thayyen } \\
(2008)\end{array}$} \\
\hline & & & & & & & 1935-1956 & 10.16 & \\
\hline & & & & & & & $\begin{array}{l}\text { July 1956-March } \\
1962\end{array}$ & 18.75 & \\
\hline & & & & & & & $\begin{array}{l}\text { March 1962- } \\
\text { September } 1971\end{array}$ & 32.21 & \\
\hline & & & & & & & 1971-1975 & 28.87 & \\
\hline & & & & & & & 1975-1977 & 36.50 & \\
\hline & & & & & & & $1977-1990$ & 28.80 & \\
\hline & & & & & & & $1935-1996$ & 18.8 & \\
\hline & & & & & & & 1996-1999 & 19 & \\
\hline \multirow[t]{5}{*}{ Milam } & \multirow[t]{5}{*}{ Goriganga } & \multirow[t]{5}{*}{18} & \multirow[t]{5}{*}{53.95} & \multirow[t]{5}{*}{ SE } & & & 1849-1906 & 12.8 & \multirow[t]{5}{*}{ GSI (1996-97) } \\
\hline & & & & & & & 1906-1938 & 16 & \\
\hline & & & & & & & 1938-1957 & 5.6 & \\
\hline & & & & & & & $1957-1966$ & 20.2 & \\
\hline & & & & & & & 1966-1997 & 30.3 & \\
\hline Burphu & Goriganga & & 11.85 & SW & & & 1966-1997 & 4.84 & GSI (1996-97) \\
\hline Dunagiri & Dauliganga & & 2.56 & $\mathrm{~N}$ & 4240 & 1984 & 1992-1997 & $\begin{array}{l}45-60 \text { total } \\
\text { advancement }\end{array}$ & GSI (1996-97) \\
\hline Chaurabari & Mandakani & 7 & & $\mathrm{~S}$ & 3840 & & 1992-1997 & $\begin{array}{l}25-55 \mathrm{~m} \text { total } \\
\text { in } 5 \text { years }\end{array}$ & GSI (1996-97) \\
\hline Hamta & Chandra & 6 & 4.5 & $\mathrm{~S}$ & 4020 & 1998 & 1963-1998 & 17.14 & GSI (1997-98) \\
\hline Nagpo Tokpo & Spiti (Satluj) & 2.7 & 2.51 & & 5240 & 1998 & 1963-1998 & 65.71 & GSI (1997-98) \\
\hline \multirow[t]{2}{*}{ Bandarpunch } & \multirow{2}{*}{$\begin{array}{l}\text { Tons } \\
\text { (Yamuna) }\end{array}$} & \multirow[t]{2}{*}{11.80} & \multirow[t]{2}{*}{22.79} & & 3940 & 1999 & 1960-1975 & 41.33 & \multirow[t]{2}{*}{ GSI (1998-99) } \\
\hline & & & & & & & 1975-1999 & 15.63 & \\
\hline \multirow{2}{*}{$\begin{array}{l}\text { Jaunder } \\
\text { Bamak }\end{array}$} & \multirow{2}{*}{$\begin{array}{l}\text { Tons } \\
\text { (Yamuna) }\end{array}$} & \multirow[t]{2}{*}{19.10} & \multirow[t]{2}{*}{57.08} & \multirow[t]{2}{*}{$\mathrm{S}$} & \multirow[t]{2}{*}{3880} & \multirow[t]{2}{*}{1999} & 1960-1975 & 20.67 & \multirow[t]{2}{*}{ GSI (1998-99) } \\
\hline & & & & & & & 1975-1999 & 47.92 & \\
\hline \multirow[t]{2}{*}{ Jhajju Bamak } & \multirow{2}{*}{$\begin{array}{l}\text { Tons } \\
\text { (Yamuna) }\end{array}$} & \multirow[t]{2}{*}{4.5} & 5.70 & $\mathrm{~S}$ & 3880 & 1999 & 1960-1975 & 5.67 & GSI (1998-99) \\
\hline & & & & & & & 1975-1999 & 41.25 & \\
\hline Tilku & Tons & 4.35 & 2.44 & $\mathrm{~S}$ & 4200 & 1999 & 1960-1975 & 5.33 & GSI (1998-99) \\
\hline & (Yamuna & & & & & & 1975-1999 & 32.29 & \\
\hline
\end{tabular}


Table 9 Continued

\begin{tabular}{|c|c|c|c|c|c|c|c|c|c|}
\hline Glacier & Basin & $\begin{array}{l}\text { Length } \\
(\mathrm{km})\end{array}$ & $\begin{array}{l}\text { Area } \\
\left(\mathrm{km}^{2}\right)\end{array}$ & Orientation & $\begin{array}{l}\text { Snout height } \\
\text { (m a.s.l.) }\end{array}$ & $\begin{array}{l}\text { Snout height } \\
\text { measurement year }\end{array}$ & $\begin{array}{l}\text { Record of } \\
\text { fluctuation in years }\end{array}$ & $\begin{array}{l}\text { Recession } \\
(\mathrm{m} / \mathrm{y})\end{array}$ & References \\
\hline Chipa & Dauliganga & 9.95 & 5 & $\mathrm{E}$ & 3527 & 2000 & $\begin{array}{l}1961-1978 \\
1978-2000\end{array}$ & $\begin{array}{l}32.35 \\
22.72\end{array}$ & GSI (1999-2000) \\
\hline Meola & Dauliganga & 10.3 & 14.02 & $\mathrm{E}$ & 3460 & 2000 & $\begin{array}{l}1961-1978 \\
1978-2000\end{array}$ & $\begin{array}{l}44.12 \\
27.27\end{array}$ & GSI (1999-2000) \\
\hline Jhulang & Dauliganga & 7 & 3.27 & $\mathrm{NE}$ & 3920 & 2000 & $1962-2000$ & 10.53 & GSI (1999-2000) \\
\hline Beas Kund & Beas & 2.1 & & $\mathrm{NE}$ & & & 1963-2003 & 18.75 & GSI (2002-03) \\
\hline Jobri & - & 3 & & NW & & & 1963-2003 & 2.5 & GSI (2002-03) \\
\hline Mantalai & Parbati & 6.5 & 11.70 & $\mathrm{NE}$ & & & 1989-2004 & 23.3 & GSI (2003-04) \\
\hline Sara Umga & - & 15.25 & 55.89 & SW & 3882 & 2004 & $\begin{array}{l}1963-1989 \\
1989-2004\end{array}$ & $\begin{array}{l}40.4 \\
43.3\end{array}$ & GSI (2003-04) \\
\hline $\begin{array}{l}\text { Bhagirathi } \\
\text { Kharak }\end{array}$ & Alaknanda & 17 & & E & 3780 & 2006 & $1962-2006$ & 7.3 & $\begin{array}{l}\text { Nainwal et al. } \\
(2008)\end{array}$ \\
\hline Satopanth & Alaknanda & 14 & & $E$ & 3870 & 2006 & 1962-2006 & 22.8 & $\begin{array}{l}\text { Nainwal et al. } \\
(2008)\end{array}$ \\
\hline Pindari & Alaknanda & & & SW & & & $\begin{array}{l}1906-1958 \\
1958-2001\end{array}$ & $\begin{array}{r}20.00 \\
12.80\end{array}$ & GSI (2000-01) \\
\hline Triloknath & Chenab & 6.5 & 6.7 & NW & 3720 & & 1969-1995 & 15.38 & GSI (1994-95) \\
\hline Chotta Shigri & Chandra & & 15.01 & $\mathrm{~N}$ & & & $\begin{array}{l}1962-1986 \\
1988-2003\end{array}$ & $\begin{array}{l}6.87 \\
53\end{array}$ & $\begin{array}{l}\text { GSI (1994-95), } \\
\text { Kulkarni (2007) }\end{array}$ \\
\hline Bara Shigri & Chandra & 29 & 137 & NW & & & $\begin{array}{l}1906-1956 \\
1956-1977 \\
1977-1995\end{array}$ & $\begin{array}{l}35 \\
11.35 \\
36.11\end{array}$ & GSI (1994-95) \\
\hline Nikarchu & Kuthiyankti & 3.9 & 7.38 & NE & & & 1962-2002 & 9.37 & GSI (2001-02) \\
\hline Adikailesh & Kuthiyankti & 2.3 & & $\mathrm{NE}$ & & & $1962-2002$ & 13 & GSI (2001-02) \\
\hline Ramganga & Kuthiyankti & 3 & & $\mathrm{~S}$ & & & $1962-2002$ & 50 & GSI (2001-02) \\
\hline Meru & Bhagirathi & 7.6 & 4.7 & $\mathrm{NE}$ & 4330 & 2000 & $\begin{array}{l}1977-1987 \\
1987-2000\end{array}$ & $\begin{array}{r}27.50 \\
9.23\end{array}$ & $\begin{array}{l}\text { Chitranshi et al. } \\
\text { (2004) }\end{array}$ \\
\hline Miyar & $\begin{array}{l}\text { Chandra } \\
\text { - Bhaga } \\
\text { (Chenab) }\end{array}$ & 27.6 & 87.78 & SE & 3940 & 1996 & $\begin{array}{l}1961-1971 \\
1971-1983 \\
1983-1996\end{array}$ & $\begin{array}{r}25 \\
8.33 \\
17.30 \\
\end{array}$ & Oberoi et al. (2001) \\
\hline
\end{tabular}


(Krishna, 2005; Racoviteanu et al., 2008b). However, mapping of debris-covered glaciers is still a challenging task, and, besides manual delineation, there is not yet a method devised which combines accuracy and a reduced amount of effort, although many debriscovered glaciers exist in the Himalayas. Prior studies on debris-covered glacier mapping, such as Paul et al. (2004), Bolch and Kamp (2006) or Bolch et al. (2007), have confirmed the relevance of DEM and thermal band information which can be applied in the Indian Himalayas. These will prove useful in the development of new methodologies for debris-covered glacier mapping in the Indian Himalayas. However, DEMs based on topographic contour are generally not available for the Indian Himalayas. Hence, the ASTER DEM provides a promising opportunity for mapping debris-covered glaciers. Its applicability has been established during the mapping of debris-covered glaciers in the Khumbu Himalayas, Tien Shan and the Alps (Bolch and Kamp, 2006; Bolch et al., 2007).

Several topographic glacier mapping studies, such as Workman (1903), Longstaff (1908; 1911), Visser (1926), Mason (1928), Shipton et al. (1938) and Mott (1950), have improved the previous maps and mapping methodology. In the current Indian scenario, however, glacier outlines based on remote sensing and GIS have not been available for the assessment of the adopted methodology due to the absence of a central database of digital glacier outlines on a country scale. In addition, a glacier inventory of the Indian Himalayas has not been executed in digital GIS format (Kaul, 1999). At present, efforts are being focused on including glacier outlines from the Himalayas in the GLIMS database (Racoviteanu et al., 2008b).

Historic glacier maps are very important for glacier research for two reasons: (1) to provide information on glacier extents into the past; and (2) to generate the contours on glacier area to assist in estimation of mass balance and volume change studies. The Survey of India publishes several maps covering glacier terrain features. Unfortunately, these maps contain inaccuracies and they are often based on aerial imagery with seasonal snowcover. It has been shown that the glacier extent on these maps can be erroneous, and the origin of the map must, therefore, be carefully checked and verified prior to use for further glacier studies.

The Geological Survey of India has mapped several glacier snouts and the surrounding glacio-geomorphic features for monitoring glacier variability since the twentieth century using plane-table mapping. Several studies by the GSI overlaid glacier outlines derived from plane-table maps onto satellite images and aerial photographs in order to find the recession rate of glaciers. However, in a practical sense, it is very difficult to identify common points on plane-table maps and satellite images for co-registration and to further overlay operations on map, satellite images and aerial photographs.

Recently, internet-based online cryospheric information system (CCIS) for several countries such as China facilitates further gathering of knowledge about the present state of glacier extent and glacier changes in their country (Li et al., 2003). The Institute of Cartography at the ETH Zurich demonstrated an internet-based Mountain Information System which is accessible for use by metadata, a visual tool relating to potential multihazards and multirisk in an alpine valley of Switzerland (Hurni, 2006). These maps support the planning efforts with regard to current water resources, and also help in designing policies for other disciplines, as regards the impact of climate change in ecosystems in mountain regions.

The errors incurred during the acquisition and analysis of glacier data in the Indian Himalayas are generally neglected, but they may have significant impacts on outcomes and conclusions. Several differences and inaccuracies in glacier mapping cannot be 
explained by climate and the topography alone. Each approach has a number of shortcomings, eg, errors in field surveying, plotting of glacier outlines on plane-table maps, coregistration of plane-table maps with topographic maps, satellite images and aerial photographs for overlay on glacier outlines, and inaccurate mapping of debris-covered glaciers. Application of techniques such as root mean square (RMS) error may be used to control the quality of the analysis and outcomes and to understand the impacts of errors on the outcomes and error propagation (Hall et al., 2003; Falorni et al., 2005). For instance, source information for each digitized glacier feature has been stored in the database of the British Ice Sheet (Clark et al., 2004). In addition, errors associated with DEMs have also been reported, as these may influence mass balance estimation (Berthier et al., 2006).

\section{Glacier variations in the Himalayas}

This review of multiple glacier records concerning length and area changes shows that glacier topography has been changing dramatically within the Indian Himalayas in the last few decades. Published records on Indian Himalayan glaciers indicate that the glaciers in the Chenab, Parbati and Baspa basins and the Garhwal Himalayas are generally in a retreating phase. However, regional trends of glacier fluctuations in Kashmir and Arunachal Pradesh are not widely known as the current fluctuation records are not available. In general, however, glaciers in the Himachal Himalayas are receding with an area loss of about $21 \%(\sim 0.52 \% / \mathrm{a})$ at a much faster rate compared with regions in Nepal. As an example, investigations in the Tamor River basin/eastern Nepal conducted in $1970-2000$ revealed that $5.88 \%$ ( 0.2\%/a) of the glacier area was deglaciated (Bajracharya and Mool, 2006). This is a higher rate than for the Khumbu Himalayas where Bolch et al. (2008) estimated, based on space imagery, a loss of ice-covered area of 5.2\% ( 0.12\%/a) from 1962 to 2005. Salerno et al. (2008) estimated, based on topographic maps, that $4.8 \%(\sim 0.12 \% / a)$ of the glacier area was deglaciated from the 1950s to the 1990s in Sagarmatha National Park, Nepal. The problems encountered in comparing maps, however, were also highlighted. In addition, it has to be noted that the large glaciers in the Khumbu area are covered with debris and the mass loss is recognizable mainly through downwasting (Bolch et al., 2008). Recession of glaciers around the Xingxinghai Lake region and the Nam Co Lake region in Tibet are estimated at about 0.5\%/a (1970-2000; Yao et al., 2007), recession rates similar to those of the Himachal Himalayas. However, the retreat rate has increased since 1990 in Tibet. A similar conclusion was reached by Fujita et al. (2001) during the study of Glacier AX010 in the Shorong region of Nepal. On average, $26 \%$ of this glacier was deglaciated $(\sim 1.25 \% / a)$ from 1978 to 1999 . However, this glacier is relatively small.

Glacier variability depends on several environmental conditions such as minimum and maximum temperature, solar radiation, and the amount of precipitation and debriscover load, as well as altitude and orientation of the glacier, which influence the mass balance of the glacier. Climate change in mountain regions has been considered as an important factor in the interpretation of glacier variability (Beniston et al., 1997; Haeberli and Beniston, 1998). Instrumental records of climatic data of Shimla (over 100 years) indicate a post-monsoon increasing temperature trend (Borgaonkar et al., 1996), which accelerates the melting of monsoonal seasonal snowcover, and this is the constraint in the conversion of snow into glacier ice. Recently, instrumental weather records from the northwestern Himalayan region for the past century show an increase in temperature of around $1.6^{\circ} \mathrm{C} / 100$ years, with winters warming at a faster rate (Bhutiyani et al., 2007). Also this study found that significant warming started from the late $1960 \mathrm{~s}$ and the highest rate of increase was in the last two decades, but no significant trend for 
precipitation has been found (Yadav, 2007). Outside the western Himalayas, Shrestha et al. (1999) found that maximum temperature trends have increased, ranging from $0.06^{\circ} \mathrm{C}$ to $1.2^{\circ} \mathrm{C}$ per year, in most of the middle mountains of the Nepal Himalayas. This indicates that temperature increase might be the major cause of the glacier recession. Debris-cover on glacier ice influences the ablation rate of glaciers, and ablation rate decreases with increases in the thickness of debris (Nakawo and Rana, 1999). The altitude of the accumulation zone is another key factor which influences the ablation of glaciers (Kulkarni, 2007). Generally speaking, Himachal Himalayan glaciers are located at low altitudes (Kulkarni et al., 2007), whereas Garhwal Himalayan glaciers are located at high ones.

Overall, the north-south and east-west irregularity of Himalayan glacier recession is affected by: snow shadow zone effects; eastto-west and south-to-north decreases in monsoonal intensity; distributions of supraglacial debris cover; altitude of accumulation zone (Kulkarni, 2007); and contributions from tributary glaciers in accumulation zones (Nainwal et al., 2008). It is predicted on the basis of regional climate models (RCM) that the temperature in the Indian subcontinent will rise by $3.5-5.5^{\circ} \mathrm{C}$ by 2100 (Kumar et al., 2006). This will have an enormous impact on the glaciers. Glacier water resources are likely to diminish and glacier-related hazards are likely to increase (Kääb et al., 2006).

\section{Conclusions and recommendations}

This review provides a comprehensive overview of the constraints and challenges relating to mapping of clean-ice and debris-covered glaciers, the comparison of different data sets and of the estimation of glacier volume changes based on multitemporal digital elevation models in the Indian Himalayas. There is a need for improvement, and possible solutions are suggested. SOI maps are imprecise for glacier terrain in some instances. Declassified imagery from intelligent spy satellites, such as
Corona imagery from the 1960s and 1970s, can be used for confirmation and improvement of the glacier outlines derived from the Survey of India maps. Glacier change studies have not been carried out over the entire Kashmir Himalayas and Arunachal Pradesh. Therefore, current efforts should focus on the generation of glacier fluctuation records from satellite images and general trends should be identified based on the study of individual basins. It is suggested that a central database for glacier outlines on a country scale in India should be maintained. In addition, glacier mapping studies based on remote sensing and GIS should include information on data quality, data error, and error propagation. Metadata should be generated during glacier inventory which can assist other investigators when comparing previous studies.

Several reports and research documents were found not to be publicly available; the sharing of research documents and data would clearly lead to the enhancement of scientific knowledge and assist in the development of new models and methods for glacier mapping, mass balance and sea-level estimations. Moreover, this would also allow others to scrutinize previous studies and improve techniques and methodology. Therefore, it is recommended that research work in the form of technical reports, research papers, maps or unpublished reports, glacier inventory data and results, mass balance data, and glacier maps be declassified and published.

It was shown that automated and semiautomated mapping of debris-covered glaciers is almost unknown for Himalayan glaciers, and there have been almost no studies published so far. Therefore, it is recommended that current efforts focus on the development of suitable automated mapping methods for debris-covered glaciers. In India, in the absence of topographic contour-based DEMs, only one study (Berthier et al., 2007) has estimated mass balance based on the geodetic approach. There exists a great opportunity to estimate mass balance from 
DEM generation based on old topographic maps and their comparison with recent high-resolution stereo data of the Indian Himalayas. Furthermore, digital photogrammetry and airborne laser altimetry could be introduced for mass balance estimation. However, due care is required while using old topographic maps, SRTM and stereo satellite data, which need validation using GPS and DGPS survey.

This study indicates that several Himalayan glaciers are retreating at an alarming rate. Therefore, it is recommended that large-scale glacier maps and potential glacier hazard maps be prepared and updated regularly at scales of $1: 5000$ to $1: 25,000$ for the monitoring of Indian Himalayan glaciers. In addition, topographic maps of glaciated terrain should be revised in order to optimize the prevention of hazards related to glacier changes (Gilgen, 2006). A glacier information system for the Indian Himalayas, providing information about the status of glacier variability and for real-time glacier related hazards, has not yet been introduced. Contemporary efforts should, therefore, focus on the preparation of an online and integrated glacier information system for the Indian Himalayas.

\section{Acknowledgements}

The authors are grateful to Ravinder Kumar Chaujar (Scientist, Wadia Institute of Himalayan Geology) for valuable guidance and support. Thanks are also due to S.K. Goyal (Principal, GNKC, Karnal) and Pushpinder Kaur (GNKC) for their wholehearted support. The authors acknowledge the inputs of Prashant Kawishwar (Resource Scientist, Department of Science and Technology, Chattisgarh) for putting down the thoughts in the paper. Furthermore, the authors thank S.C. Kulshreshtha (Reader, SD College, Muzaffarnagar) and Virender Kumar (ex Chief Engineer, Irrigation Department, UP) for fruitful discussions on the presented research. We are also grateful to Lokesh Sharma (Librarian, Ratan Tata Library, Delhi University, and Librarian, Geological Survey of India, Lucknow) for providing valuable references. The authors also express their appreciation to C.V. Sangwar and S.P. Shukla (Glaciology Division, GSI-Lucknow) for thoughtful discussion on glacier mapping. The first author extends special thanks to Gopal Rao (former Surveyor General of India) and several Public Information Officers for providing valuable information without which this research would not have been possible. The authors extend their gratitude to Nick Clifford (Managing Editor, Progress in Physical Geography) for his insightful comments and suggestions, which significantly improved the flow and content of this paper. Further thanks are directed to Susan Braun-Clarke who polished the English. The second author was partly funded by the German Research Foundation (Deutsche Forschungsgemeinschaft, DFG) under the code BU 949/15-1. ASTER data was provided at no cost by NASA/USGS under the umbrella of the GLIMS project.

\section{References}

Agarwal, N.K. 1989: Terrestrial photogrammetric mapping of the Neh-Nar glacier in Himalayas, India. ISPRS Journal of Photogrammetry and Remote Sensing 44, 245-52.

Agarwal, N.K. 2001: Remote sensing for glacier mapping and monitoring. Geological Survey of India Special Publication 53, 201-206.

Ahmad, S. and Hasnain, S.I. 2004: Analysis of satellite imageries for characterization of glacio-morphological features of the Gangotri Glacier, Ganga headwater, Garhwal Himalayas. In Srivastava, D., Gupta. K.R. and Mukerji. S., editors, Geological Survey of India Special Publication 80, 61-67.

Andreassen, L.M. 1999: Comparing traditional mass balance measurements with long-term volume change extracted from topographical maps: a case study of Storbreen glacier in Jotnnheimen, Norway, for the period 1940-1997. Geografiska Annaler: Series A, Physical Geography 81, 467-76.

Andreassen, L.M., Paul, F., Kääb, A. and Hausberg, J.E. 2008: Landsat-derived glacier inventory for Jotunheimen, Norway, and deduced glacier changes since the 1930s. The Cryosphere 2, 131-45.

Ashwell, I.Y. 1982: Glacier mapping in Iceland by the British Schools Exploring Society. The Geographical Journal 148, 308-16. 
Auden, J.B. 1937: Snout of the Gangotri Glacier, Tehri Garhwal. Records of the Geological Survey of India 72, $135-40$.

Bahr, D.B. 1997: Width and length scaling of glaciers. Journal of Glaciology 43, 557-62.

Bahuguna, I.M. 2008: Himalayan glaciers. ISG Newsletter 14, 36-43.

Bahuguna, I.M., Kulkarni, A.V. and Nayak, S. 2004: DEM from IRS-1C PAN stereo coverages over Himalayan glaciated region - accuracy and its utility. International Journal of Remote Sensing 25, 4029-41.

Bahuguna, I.M., Kulkarni, A.V., Nayak, S., Rathore, B.P., Negi, H.S. and Mather, P. 2007: Himalayan glacier retreat using IRS IC PAN stereo data. International Journal of Remote Sensing 28, 437-42.

Bajracharya, S.R. and Mool, P.K. 2006: Impact of global climate change from 1970s to 2000s on the glaciers and glacial lakes in Tamor Basin, eastern Nepal. Unpublished report for ICIMOD, Kathmandu.

Bamber, J.L. and Rivera, A. 2007: A review of remote sensing methods for glacier mass balance determination. Global and Planetary Change 59, 138-48.

Bauder, A., Funk, M. and Huss, M. 2007: Icevolume changes of glaciers in the Swiss Alps. Annals of Glaciology 46, 145-49.

Bayr, I.J., Hall, D.K. and Kovalick, W.M. 1994: Observations on glaciers in the eastern Austrian Alps using satellite data. International Journal of Remote Sensing 15, 1733-42.

Beniston, M., Diaz, H.F. and Bradley, R.S. 1997: Climatic change at high elevation sites: an overview. Climatic Change 36, 233-51.

Berthier, E., Arnaud, Y., Kumar, R., Ahmad, S., Wagnon, P. and Chevallier, P. 2007: Remote sensing estimates of glacier mass balances in the Himachal Pradesh (Western Himalayas, India). Remote Sensing of Environment 108, 327-38.

Berthier, E., Arnaud, Y., Vincent, C. and Remy, F. 2006: Biases of SRTM in high-mountain areas: implications for the monitoring of glacier volume changes. Geophysical Research Letters 33, L08502, DOI: 10.1029/2006GL025862.

Bhutiyani, M.R., Kale, V.S. and Pawar, N.J. 2007: Long-term trends in maximum, minimum and mean annual air temperatures across the northwestern Himalaya during the 20th Century. Climatic Change 85, 159-77.

Bishop, M.P. and Colby, J.D. 2002: Anisotropic reflectance correction of SPOT-3 HRV imagery. International Journal of Remote Sensing 23, 2125-31.

Bishop, M.P., Bonk, R., Kamp, U. and Shroder J.F. Jr 2001: Terrain analysis and data modeling for alpine glacier mapping. Polar Geography 25, 182-201.

Bolch, T. 2007: Climate change and glacier retreat in northern Tien Shan (Kazakhstan/Kyrgyzstan) using remote sensing data. Global Planet Change 56, 1-12.
Bolch, T. 2008: Klima- und Gletscheränderungen im nördlichen Tien Shan (Kasachstan/Kyrgyzstan) mit einem Vergleich zur Bernina-Gruppe/Alpen (in German with English and Russian summaries and captions). Saarbrücken: VDM Verlag Dr. Müller, $210 \mathrm{pp}$. Also available as a dissertation, Universität Erlangen-Nürnberg; retrieved 2 September 2009 from http://www.opus.ub.uni-erlangen.de/opus/ volltexte/2006/447

Bolch, T. and Kamp, U. 2006: Glacier mapping in high mountains using DEMs, Landsat and ASTER Data. Grazer Schriften der Geographie und Raumforschung (Proceedings of the 8th International Symposium on High Mountain Remote Sensing Cartography, 20-27 March 2005, La Paz, Bolivia) 41, 13-24.

Bolch, T., Buchroithner, M.F., Kunert, A. and Kamp, U. 2007: Automated delineation of debriscovered glaciers based on ASTER data. In Gomarasca, M.A., editor, Geolnformation in Europe (Proceedings of 27th EARSeL Symposium, 4-7 June, Bozen, Italy), Rotterdam: Millpress, 403-10.

Bolch, T., Buchroithner, M.F., Pieczonka, T. and Kunert, A. 2008: Planimetric and volumetric Glacier changes in Khumbu Himalayas since 1962 using Corona, Landsat TM and ASTER data. Journal of Glaciology 54, 592-600.

Bolch, T., Kamp, U. and Olsenholler, J. 2005: Using ASTER and SRTM DEMs for studying geomorphology and glaciation in high mountain areas. In Oluic, M., editor, New strategies for European remote sensing, Rotterdam: Millpress, 119-27.

Bolch, T., Menounos, B. and Wheate, R. 2009 : Landsat-based glacier inventory of western Canada, 1985-2005. Remote Sensing of Environment, DOI: 10.1016/j.rse.2009.08.015.

Borgaonkar, H.P., Pant, G.B. and Kumar, K.R. 1996: Ring-width variations in Cedrus deodara and its climatic response over the western Himalayas. International Journal of Climatology, 1409-22.

Brocklehurst, S.H. and Whipple, K.X. 2004: Hypsometry of glaciated landscapes. Earth Surface Process and Landforms 29, 907-26.

Brunner, K. 1987: Glacier mapping in the Alps. Mountain Research and Development 7, 375-85.

Buckley, A., Hurni, L., Kriz, K., Patterson, T. and Olsenholler, J. 2004: Cartography and visualization in mountain geomorphology. In Bishop, M.P. and Shroder, J.F. Jr, editors, Geographic Information Science and mountain geomorphology, Chichester: Springer-Praxis, 253-87.

Campbell, G.J. 2005: Inventory of glaciers, glacial lakes and the identification of potential glacial lake outburst floods (GLOFs) affected by global warming in the mountains of India, Pakistan and China/Tibet Autonomous Region. Overview of project work and outcomes: non-technical summary of APN Project 2004-03, 48 pp. 
Chaujar, R.K. 1989: Glacial geomorphology - a case study of Chota Shigri Glacier. In Proceedings of National Meet on Himalayan Glaciology, New Delhi: Ministry of Science and Technology, Government of India, 173-85.

Chen, J. and Ohmura, A. 1990: Estimation of Alpine glacier water resources and their change since 1870s. IAHS Publication 193, 127-35.

Chitranshi, A., Sangewar, C.V., Srivastava, D., Puri, V.M.K. and Dutta, S.S. 2004: Recession pattern of Meru Bamak Glacier, Bhagirathi Basin, Uttaranchal. In Srivastava, D., Gupta. K.R. and Mukerji. S., editors, Geological Survey of India Special Publication 80, 33-38.

Clark, C.D., Evans, D.J.A., Khatwa, A., Bradwell, T., Jordan, C., Marsh, S.H., Mitchell, W.A. and Bateman M.D. 2004: Map and GIS database of glacial landforms and features related to the last British Ice Sheet. Boreas 33, 359-75.

Conway, W.M. 1893: The crossing of the Hispar Pass. Geographical Journal 1, 23-33.

Dhanju, M.S. and Buch, A. 1989: Remote sensing of Himalayan glaciers. In Proceedings of National Meet on Himalayan Glaciology, New Delhi: Ministry of Science and Technology, Government of India, 193-213.

Dobhal, D.P. and Kumar, S. 1996: Inventory of glacier basins in Himachal Himalayas. Journal of Geological Society of India 48, 671-81.

Dobhal, D.P., Gergan, J.T. and Thayyen, R.J. 2004: Recession and morphogeometrical changes of Dokriani glacier (1962-1995) Garhwal Himalayas, India. Current Science 86, 692-96.

Dobhal, D.P., Gergan, J.T. and Thayyen, R.J. 2007: Mass balance and snout recession measurements (1991-2000) of Dokriani Glacier, Garhwal Himalayas, India. In Mahé, G., editor, Climatic and anthropogenic impacts on the variability of water resources, UNESCO, Technical Document in Hydrology 80, 53-63.

Dutta, S.S., Sangewar, C.V., Shukla, S.P., Chitranshi, A., Puri, V.M.K. and Hampaiah, P. 2004: Some observation on physiography and geomorphology of Gangotri glacier area, Bhagirathi basin, Uttaranchal. In Srivastava, D., Gupta, K.R. and Mukerji, S., editors, Geological Survey of India Special Publication 80, 69-78.

Dyurgerov, M.B. and Meier, M. 1997: Mass balance of mountain and subpolar glaciers: a new global assessment for 1961-1990. Arctic and Alpine Research 29, 379-91.

Etzelmüller, B. and Sollid, J.L. 1997: Glacier geomorphometry - an approach for analyzing longterm glacier surface changes using grid-based digital elevation models. Annals of Glaciology 24, 135-41.

Etzelmüller, B., Hoelzle, M., Heggem, E.S.F., Isaksen, K., Mittaz, C., Vonder Mühll, D., Ødegård, R.S., Haeberli, W. and Sollid, J.L.
2001: Mapping and modelling the occurrence and distribution of mountain permafrost. Norwegian Journal of Geography 55, 186-94.

Falorni, G., Teles, V., Vivoni, E.R., Bras, R.L. and Amaratunga, K.S. 2005: Analysis and characterization of the vertical accuracy of digital elevation models from the Shuttle Radar Topography Mission. Geophysical Research Letters 110, F02005, DOI: 10.1029/2003JF000113.

Filippo de Filippi 1911: The expedition of H.R.H. the Duke of the Abruzzi to the Karakoram Himalayas. The Geographical Journal 37, 19-25.

Finsterwalder, R. 1935: On the map of the Zemu Glacier. Himalayan Journal 7, 125-38.

Finsterwalder, R. 1984: Utilization of orthophotographs in the mapping of high mountain regions. Mountain Research and Development 4, 315-18.

Finsterwalder, R. and Pillewizer, W. 1937 : Photogrammetric studies of glaciers of High Asia. Himalayan Journal 11, 107-13.

Fujita, K. , Kadota, T., Rana, B., Kayastha, R. B. and Ageta, Y. 2001: Shrinkage of Glacier AX010 in Shorong region, Nepal Himalayas in the 1990s. Bulletin of Glaciological Research 18, 51-54.

Geological Survey of India (GSI) 1994-95: Annual general report, Part 8. Volume 129.

Geological Survey of India (GSI) 1995-96: Annual general report, Part 8. Volume 130.

Geological Survey of India (GSI) 1996-97: Annual general report, Part 8. Volume 131.

Geological Survey of India (GSI) 1997-98: Annual general report, Part 8. Volume 132.

Geological Survey of India (GSI) 1998-99: Annual general report, Part 8. Volume 133.

Geological Survey of India (GSI) 1999-2000: Annual general report, Part 8. Volume 134.

Geological Survey of India (GSI) 2000-01: Annual general report, Part 8. Volume 135.

Geological Survey of India (GSI) 2001-02: Annual general report, Part 8. Volume 136.

Geological Survey of India (GSI) 2002-03: Annual general report, Part 8. Volume 137.

Geological Survey of India (GSI) 2003-04: Annual general report, Part 8. Volume 138.

Gilgen, J. 2006: Revision of rock, scree and glacier in a databased cartographic system. In Proceedings of 5th Mountain Cartography Workshop of the Commission on Mountain Cartography of the ICA, Bohinj, Slovenia, 29 March-1 April. Retrieved 2 September 2009 from http://www.mountaincartography.org/publications/ papers/papers_bohinj_06/06_Gilgen.pdf

Godwin-Austen, H.H. 1864: On the glaciers of the Mustagh Range. Journal of Royal Geographical Society 34, 19-56.

Gupta, R.P., Haritashya, U.K. and Singh, P. 2005: Mapping dry/wet snow cover using IRS multispectral data in the Himalayas. Remote Sensing of Environment 97, 458-69. 
Haeberli, W. and Beniston, M. 1998: Climate change and its impacts on glaciers and permafrost in the Alps. Ambio 27, 258-65.

Hall, D.K., Bahr, K.J., Shoener, W. , Bindschadler, R.A. and Chien, J.Y.L. 2003: Consideration of the errors inherent in mapping historical glacier positions in Austria from the ground and space. Remote Sensing of Environment 86, 566-77.

Hall, D.K., Riggs, G.A. and Salomonson, V.V. 1995: Development of methods for mapping global snow cover using Moderate Resolution Imaging Spectroradiometer (MODIS) data. Remote Sensing of Environment 54, 127-40.

Hall, D.K., Williams, R.S. Jr and Bayr, K.J. 1992: Glacier recession in Iceland and Austria. EOS, Transactions of the American Geophysical Union 73, 135-41.

Hasnain, S.I. 1999: Himalayan glaciers - hydrology and hydrochemistry. New Delhi: Allied Publishers, 234 pp.

Hirano, A., Welch, R. and Lang, H. 2003: Mapping from ASTER stereo image data: DEM validation and accuracy assessment. ISPRS Journal of Photogrammetry and Remote Sensing 57, 356-70.

Holland, T.H. 1907: A preliminary survey of certain glaciers in the North-West Himalayas. Records of the Geological Survey of India 35, 47-52.

Hurni, L. 2006: What makes cartography interesting for mountain researchers? In Proceedings of 5th Mountain Cartography Workshop of the Commission on Mountain Cartography of the ICA, Bohinj, Slovenia, 29 March-1 April. Retrieved 2 September 2009 from http://www.mountaincartography.org/ publications/papers/papers_bohinj_06/10_Hurni_ etal.pdf

Jangpangi, B.S. 1958: Report on the survey and glaciological study of the Gangotri glacier, Tehri Garhwal District: Glacier No 3, Arwa Valley: Satopanth and Bhagirath Kharak Glaciers, Garhwal District, Uttar Pradesh. Memoirs of the Geological Survey of India, $18 \mathrm{pp}$.

Kääb, A., Huggel, C. and Fischer, L. 2006: Remote sensing technologies for monitoring climate change impacts on glacier- and permafrost-related hazards. ECI Conference on Geohazards, Paper 2, 12 pp.

Kääb, A., Huggel, C., Paul, F., Wessels, R., Raup, B., Kieffer, H. and Kargel, J. 2003: Glacier monitoring from ASTER imagery: accuracy and applications. EARSEL eProceedings 2, 43-53.

Kargel, J., Abrams, M., Bishop, M., Bush, A., Hamilton, G. and Jiskoot, H. 2005: Multispectral imaging contributions to global land ice measurements from space. Remote Sensing of Environment 99, 187-219.

Kaul, M.K. 1999: Inventory of the Himalayan glaciers: a contribution to the International Hydrological Programme. Kolkata: Geological Survey of India, 165 pp.
Kaushal, A., Singh, Y.K., Pal, D.J. and Mathur, P. 2004: Snow class stratification and snow line monitoring of a glacier in North Himalayas using advanced remote sensing techniques. In International Symposium on Snow Monitoring and Avalanches, Manali, $4 \mathrm{pp}$

Keutterling, A. and Thomas, A. 2006: Monitoring glacier elevation and volume changes with digital photogrammetry and GIS at Gepatschferner glacier, Austria. International Journal of Remote Sensing 27, 4371-80.

Krishna, A.P. 2005: Snow and glacier cover assessment in the high mountains of Sikkim Himalayas. Hydrological Processes 19, 2375-83.

Kulkarni, A.V. 1991: Glacier inventory in Himachal Pradesh using satellite images. Journal of Indian Society of Remote Sensing 19, 195-203.

Kulkarni, A.V. 1992: Mass balance of Himalayan glaciers using AAR and ELA methods. Journal of Glaciology 38, 101-104.

Kulkarni, A.V. 2007: Effect of global warming on Himalayan cryosphere. Jalvigyan Sameeksha 22, 93-107.

Kulkarni, A.V. and Suja, A. 2003: Estimation of recent glacial variations in Baspa Basin using remote sensing techniques. Journal of Indian Society of Remote Sensing 31, 81-90.

Kulkarni, A.V., Bahuguna, I.M., Rathore, B.P., Singh, S.K., Randhawa, S.S., Sood, R.K. and Dhar, S. 2007: Glacial retreat in Himalayas using Indian remote sensing satellite data. Current Science $92,69-74$.

Kulkarni, A. V., Mathur, P., Rathore, B.P., Suja, A., Thakur, N. and Manoj, K. 2002: Effect of global warming on snow ablation pattern in the Himalayas. Current Science 83, 120-23.

Kulkarni, A.V., Philip, G., Thakur, V.C., Sood, R.K., Randhawa, S.S. and Ram, C. 1999: Glacial inventory of the Satluj Basin using remote sensing technique. Journal of Himalayan Geology 20, 45-52.

Kulkarni, A.V., Rathore, B.P., Mahajan, S. and Mathur, P. 2005: Alarming retreat of Parbati glacier, Beas basin, Himachal Pradesh, Current Science 88, 1844-49.

Kulkarni, A.V., Rathore, B.P. and Suja, A. 2004 : Monitoring of glacial mass balance in the Baspa basin using accumulation area ratio method. Current Science 86, 101-106.

Kumar, R. K., Sahai, A. K. , Krishna, K., Patwardhan, S.K., Mishra, P.K., Revadekar, J.V., Kamala, K. and Pant, G.B. 2006: High-resolution climate change scenarios for India for the 21 st century. Current Science 90, 334-45.

Kumar, R., Singh, R.D. and Sharma K.D. 2005: Water resources of India. Current Science 89, 774-811.

Leonard, K.C. and Fountain, A.G. 2003: Mapbased methods for estimating glacier equilibriumline altitudes. Journal of Glaciology 49, 329-36. 
Li, X., Cheng, G., Wu, Q. and Ding, Y. 2003: Modeling Chinese cryospheric change by using GIS technology. Cold Regions Science and Technology 36, 1-9.

Longstaff, T.G. 1908: A mountaineering expedition to Himalayas of Garhwal. The Geographical Journal 31, 361-88.

Longstaff, T.G. 1910a: Dr. Longstaff's Himalayan expedition, 1909. The Geographical Journal 35, 64-65.

Longstaff, T.G. 1910b: Glacier exploration in the eastern Karakoram. The Geographical Journal 35, 622-58.

Longstaff, T.G. 1911: The survey of the Himalayas. The Geographical Journal 37, 195-98.

Mason, K. 1914: The Indo-Russian triangulation connection. The Geographical Journal, 664-72.

Mason, K. 1927a: The Shaksgam Valley and Aghil Range. The Geographical Journal 69, 289-323.

Mason, K. 1927b: The stereographic survey of the Shaksgam. The Geographical Journal 70, 342-52.

Mason, K. 1928: Note on Sir Francis Younghusband's Urdok Glacier. The Geographical Journal 71, 275-77.

Mason, K. 1929: The representation of glaciated regions on maps of the Survey of India. Professional Paper 25. Dehradun: Geodetic Branch, Survey of India, $18 \mathrm{pp}$.

Mayewski, P.A. and Jeschke, P.A. 1979: Himalayan and trans-Himalayan glacier fluctuations since AD 1812. Arctic and Alpine Research 11, 267-87.

Mool, P.K., Bajracharrya, S.R. and Joshi, S.P. 2007: Inventory of glaciers, glacial lakes, glacial lake outburst floods: monitoring and early warning systems in the Hindu Kush-Himalayan Region, Nepal. Kathmandu: ICIMOD, 386 pp.

Mott, P.G. 1950: Karakoram Survey, 1939: a new map. The Geographical Journal 116, 89-95.

Mukherjee, B.P. and Sangewar, C.V. 2001: Recession of Gangotri glacier through 20th century. Geological Survey of India Special Publication 65, 1-3.

Nainwal, H.C., Negi, B.D.S., Chaudhary, M., Sajwan, K.S. and Gaurav, A. 2008: Temporal changes in rate of recession: evidence from Satopanth and Bhagirath Kharak glaciers, Uttarakhand, using Total Station Survey. Current Science 94, 653-60.

Naithani, A.K., Nainwal, H.C., Sati, K.K. and Prasad, C. 2001: Geomorphological evidences of retreat of the Gangotri glacier and its characteristics. Current Science 80, 87-94.

Nakawo, M. and Rana, B. 1999: Estimate of ablation rate of glacier ice under a supraglacial debris layer. Geografiska Annaler 81, 695-701.

Narama, C., Shimaura, Y., Nakayama, D. and Abdrakhmatov, K.E. 2006: Recent changes of glacier coverage in the western Terskey-Alatoo Range, Kyrgyz Republic, using Corona and Landsat. Annals of Glaciology 43, 223-29.

Negi, H.S., Thakur, N.K. and Mishra, V.D. 2007: Estimation and validation of snow surface temperature using modis data for snow-avalanche studies in NW-Himalaya. Journal of the Indian Society of Remote Sensing 35, 287-99.

Oberoi, L.K., Siddiqui, M.A. and Srivastava, D. 2001: Recession pattern of Miyar glacier, Lahaul and Spiti district, Himachal Pradesh. Geological Survey of India Special Publication 65, 57-60.

Østrem, G. and Haakensen, N. 1999: Map comparison or traditional mass-balance measurements: which method is better? Geografiska Annaler 81, 703-11.

Paul, F. 2001: Evaluation of different methods for glacier mapping using Landsat TM. Workshop on Land Ice and Snow, Dresden/FRG, 16-17 June, 2000. EARSeL eProceedings 1, 239-45.

Paul, F. and Haeberli, W. 2008: Spatial variability of glacier elevation changes in the Swiss Alps obtained from two digital elevation models. Geophysical Research Letters 35, L21502, DOI: 10.1029/2008GL034718.

Paul, F. and Kääb, A. 2005: Perspectives on the production of a glacier inventory from multispectral satellite data in Arctic Canada: Cumberland Peninsula, Baffin Island. Annals of Glaciology 42, 59-66.

Paul, F., Huggel, C. and Kääb, A. 2004: Mapping of debris-covered glaciers using multispectral and DEM classifcation techniques. Remote Sensing of Environment 89, 510-18.

Paul, F., Kääb, A., Maisch, M., Kellenberger, T., and Haeberli, W. 2001: The new remote sensing derived Swiss glacier inventory. I: Methods. Annals of Glaciology 34, 355-61.

Philip, G. and Ravindran, K.V. 1998: Glacial mapping using Landsat Thematic mapper data: a case study in parts of Gangotri glacier, NW Himalayas. Indian Journal of Remote Sensing 26, 29-34.

Philip, G. and Sah, M.P. 2004: Mapping repeated surges and retread of glaciers using IRS - IC/1D data: a case study of Shaune Garang glacier, northestern Himalayas. International Journal of Applied Earth Observation and Geoinformation 6, 127-41.

Pope, A., Murray, T. and Luckman, A. 2007: DEM quality assessment for quantification of glacier surface change. Annals of Glaciology 46, 189-94.

Purdon, W. 1861: On the trigonometrical survey and physical configuration of the Valley of Kashmir. Journal of the Royal Geographical Society of London 31, 14-30.

Rabatel, A., Dedieu, J.P. and Vincent, C. 2005: Using remote-sensing data to determine equilibriumline altitude and mass-balance time series: validation on three French glaciers, 1994-2002. Journal of Glaciology 51, 539-46.

Racoviteanu, A.E., Arnaud, Y., Williams, M.W. and Ordonez, J. 2008a: Decadal changes in glacier parameters in the Cordillera Blanca, Peru, derived from remote sensing. Journal of Glaciology 54, 499-510. 
Racoviteanu, A.E., Manley, W.F., Arnaud, Y. and Williams, M. 2007: Evaluating digital elevation models for glaciologic applications: an example from Nevado Coropuna, Peruvian Andes. Global Planet Change 59, 110-25.

Racoviteanu, A., Williams, M.W. and Barry, R.G. 2008b: Optical remote sensing of glacier characteristics: a review with focus on the Himalayas. Sensors 8, 3355-83.

Raina, V.K. and Srivastava, D. 2008: Glacier atlas of India. Bangalore: Geological Society of India, 316 pp.

Ranzi, R., Grossi, G., Iacovelli, L. and Taschner, T. 2004: Use of multispectral ASTER images for mapping debris-covered glaciers within the GLIMS Project. IEEE International Geoscience and Remote Sensing Symposium II, 1144-47.

Raup, B.H., Kääb, A., Kargel, J.S., Bishop, M.P., Hamilton, G., Lee, E., Paul, F., Rau, F., Soltesz, D., Khalsa, S.J.S., Beedle, M. and Helm, C. 2007: Remote sensing and GIS technology in the Global Land Ice Measurements from Space (GLIMS) project. Computers and Geosciences 33, 104-25.

Rignot, E., Rivera, A. and Casassa, G. 2003: Contribution of the Patagonia icefields of South America to sea level rise. Science 302, 434-37.

Rivera, A., Benham, T., Casassa, G., Bamber, J.L. and Dowdeswell, J.A. 2007: Ice elevation and areal changes of glaciers from the Northern Patagonian icefield, Chile. Global and Planetary Change 59, 126-37.

Rivera, A., Casassa, G., Bamber, J.L. and Kääb, A. 2005: Ice elevation changes on Glaciar Chico, Southern Patagonian Icefield, Chile. Journal of Glaciology 172, 105-12.

Rott, H. 1994: Thematic studies in alpine areas by means of polarmetric SAR and optical imagery. Advances in Space Research 14, 217-26.

Roy, B.C. 2001: Geodatic, geophysical and surveying techniques for evaluation of glacier mass balance and dynamics. Geological Survey of India Special Publication 53, 337-45.

Salerno, F., Tartari, G., Buraschi, E., Bruccoleri, G. and Smiraglia, C. 2008: Surface area variations of Sagarmatha National Park (Nepal) glaciers in the second half of the 20th century by comparison of historical maps. Journal of Glaciology 54, 738-52.

Sangwar, C.V., Hampaiah, P., Siddiqui, M.A., Maruthi, K.V. and Srivastava, K.K. 2004 : Morphometry of Bhagirathi basin, Garhwal Himalayas. In Srivastava, D., Gupta, K.R. and Mukerii, S., editors, Geological Survey of India Special Publication 80, 227-34.

Schiefer, E., Menounos, B. and Wheate, R. 2007: Recent volume loss of British Columbia glaciers, Canada. Geophysical Research Letters 34, L16503, DOI: 10.1029/2007GL030780.
Sharma, M.C. and Owen, L.A. 1996: Quaternary glacial history of the Garhwal Himalayas, India. Quaternary Science Reviews 15, 335-65.

Shipton, E., Spender, M. and Auden, J.B. 1938: The Shaksgam Expedition, 1937. The Geographical Journal 91, 313-36.

Shrestha, A.B., Wake, C.P., Mayewsk, P.A. and Dibb, J.E. 1999: Maximum temperature trends in the Himalaya and its vicinity: an analysis based on the temperature records from Nepal for the period 1971-94. Journal of Climate, 2775-86.

Shroder, J.F. Jr, Bishop, M.P., Sloan, V. and Copland, L. 2000: Debris-covered glaciers and rock glaciers in the Nanga Parbat Himalayas, Pakistan. Geografiska Annaler 82, 17-31.

Sidjak, R. and Wheate, R. 1999: Glacier mapping of the Illecillewaet icefield, British Columbia, Canada, using Landsat TM and digital elevation data. International Journal of Remote Sensing 20, 273-84.

Srivastava, D. 2001: Glaciology of Indian Himalayas: a bilingual contribution in 150 years of Geological Survey of India. Geological Survey of India Special Publication 63, 213 pp.

Srivastava, D. 2004: Recession of Gangotri glacier. In Srivastava, D., Gupta, K.R. and Mukerji, S., editors, Geological Survey of India Special Publication 80, 21-32.

Srivastava, D., Swaroop, S., Mukerjee, B.P. and Shukla, S.P. 1995: Integrated snow, ice, avalanche and quaternary glaciological studies in Mandakini valley, around Kedarnath, Chamoli district, UP. Records of Geological Survey of India 128, 220-23.

Surazakov, A.B. and Aizen, V.B. 2006: Estimating volume change of mountain glaciers using SRTM and map-based topographic data. IEEE Transactions on Geoscience and Remote Sensing 44, 2991-95.

Survey of India 2005: National map policy. Retrieved 2 September 2009 from http://www. surveyofindia.gov.in/tenders/nationalmappolicy/ nationalmappolicy.pdf

Thayyen, R.J. 2008: Lower recession rate of Gangotri glacier during 1971-2004. Current Science 95, 9-10.

Tiwari, A.P. 1972: Study of the Gangotri Glacier, Uttarkashi, Central Himalayas, U.P. Records of Geological Survey of India 106, 248-56.

Toutin, T. 2008: ASTER DEMs for geomatic and geoscientific applications: a review. International Journal of Remote Sensing 29, 1855-75.

Vignon, F., Arnaud, Y. and Kaser, G. 2003: Quantification of glacier volume change using topographic and ASTER DEMs: a case study in the Cordillera Blanca. In Proceedings of Geoscience and Remote Sensing Symposium IGARSS'03, IEEE International, 2605-607.

Visser, C. 1926: Explorations in the Karakoram. The Geographical Journal 68, 457-68. 
Visser, C. 1934: The Karakoram and Turkestan Expedition of 1929-1930. The Geographical Journal 84, 281-95.

Vohra, C.P. 1980: Some problems of glacier inventory in the Himalayas. In Proceedings of the Riederalp Workshop, September 1978, IAHS-AISH Publication 126, 67-74.

Williams, M.W. 1986: Glacier inventories of Iceland: evaluation and use of sources of data. Annals of Glaciology 8, 184-91.

Williams, R.S. Jr and Ferrigno, J.G., editors 1988 2008: Satellite image atlas of the glaciers of the world. USGS Professional Paper 1386, A-K.

Workman, F.B. 1906: First exploration of the Hoh Lumba and Sosbon Glaciers: two pioneer ascents in the Himalayas. The Geographical Journal 27, 129-41.

Workman, H. 1903: Summer tour to Baltistan. The Geographical Journal 22, 541.

WWF 2005: An overview of glaciers, glacier retreat, and subsequent impacts in Nepal, India and China. Retrieved 2 September 2009 from http://assets.panda. org/downloads/himalayaglaciersreport2005.pdf
Yadav, R.R. 2007: Basin specificity of climate change in western Himalaya, India: tree-ring evidence. Current Science 92, 1424-29.

Yao, T., Pu, J., Lu, A., Wang, Y. and Yu, W. 2007: Recent glacial retreat and its impact on the hydrological processes on the Tibetan Plateau, China, and surrounding regions. Arctic Antarctic and Alpine Research 39, 642-50.

Zemp, M., Haeberli, W., Bajracharya, S., Chinn, T.J., Fountain, A.G., Hagen, J.O., Huggel, C., Kääb, A., Kaltenborn, B.P., Karki, M., Kaser, G., Kotlyakov, V.M., Lambrechts, C., Li, Z.Q., Molnia, B.F., Mool, P., Nellemann, C., Novikov, V., Osipova, G.B., Rivera, A., Shrestha, B., Svoboda, F., Tsvetkov, D.G. and Yao, T.D. 2007: Glaciers and ice caps. Part I: Global overview and outlook. Part II: Glacier changes around the world. In UNEP: Global outlook for ice and snow, Arendal: UNEP/GRID-Arendal. 


\section{Erratum}

Progress in Physical Geography

(C) The Author(s) 2010

Reprints and permission:

sagepub.co.uk/journalsPermissions.nav

DOI: |0.1 |77/0309|3331036386|

PPg.sagepub.com

@SAGE

Rakesh Bhambri and Tobias Bolch: Glacier mapping: a review with special reference to the Indian Himalayas.

Progress in Physical Geography, 2009.

(Original DOI: 10.1177/0309133309348112)

This article contains the following errors:

Page 691, first sentence of third paragraph should read:

In the Alaknanda basin, the ice-covered area of Satopanth Glacier diminished by $0.314 \mathrm{~km}^{2}$ (1.5\%) near the snout from 1962 to 2006, whereas Bhagirathi Kharak Glacier lost an area of $0.129 \mathrm{~km}^{2}(0.4 \%)$ during a similar time period (Nainwal et al., 2008).

Page 685, Table 4, Rivera et al. (2005) observations and outcomes should read:

This study found a maximum ice thinning of $5.4 \pm 0.55 \mathrm{~m} \mathrm{a}^{-1}(\ldots)$

Page 686, Table 4, second sentence of Schiefer et al. (2007) observations and outcomes should read:

After bias correction, the thinning rate was estimated at $0.78 \pm 0.19 \mathrm{~m} \mathrm{a}^{-1}$ in this study
Page 691, lines 5-11 of second column should read:

Kulkarni et al. (2007) concluded that the number of glaciers increased between 1962 and 2001 due to disintegration of larger glacier masses. This study suggests that glaciers $<1 \mathrm{~km}^{2}$ lost $38 \%$ ( 0.95\%/a) of their 1962 area (...)

Page 691, lines 13-17 of second column should read:

Similarly, several studies outside the Himalayas such as in the Swiss Alps suggest that glaciers $<1 \mathrm{~km}^{2}$ lost $57 \%$ of their area $(\sim 2.1 \% / \mathrm{a})$ during 1973 to 2000 (Zemp et al., 2007).

Page 692, lines 14-15 should read:

Kulkarni et al. (2005) estimated an average recession rate of $168 \mathrm{~m} / \mathrm{a}$ for the Parbati Glacier from 1962 to $2001(\ldots)$ 